\title{
Effects of Working Memory Training on Phonological Awareness, Word Recognition, and Working Memory in Pre-school Korean-English Bilingual Children
}

\author{
Yoon Ah Kim ${ }^{\mathrm{a}}$, Heeyoung Park ${ }^{\mathrm{b}}$, Young Tae Kim ${ }^{\mathrm{b}}$ \\ ${ }^{a}$ Registered Nurse Team, Lions Haven for the Aged, Hope Island, Queensland, Australia \\ ${ }^{b}$ Department of Communication Disorders, Ewha Womans University, Seoul, Korea
}

\author{
Correspondence: Young Tae Kim, PhD \\ Department of Communication Disorders, Ewha \\ Womans University, 52 Ewhayeodae-gil, \\ Seodaemun-gu, Seoul 03760, Korea \\ Tel: $+82-2-3277-2120$ \\ Fax: +82-2-3277-2122 \\ E-mail: youngtae@ewha.ac.kr
}

Received: July 5, 2019

Revised: August 13, 2019

Accepted: August 13, 2019

This study is based on a master's thesis submitted by the first author to the Department of Communication Disorders, Ewha Womans University, in partial fulfillment of the requirements for the master's degree.

This work was supported by the Ministry of Education of the Republic of Korea and the National Research Foundation of Korea (No. NRF2018S1A3A2075274).
Objectives: This study investigated whether verbal working memory training could improve the phonological awareness, word recognition, and working memory in pre-school bilingual children. Methods: Twenty-two Korean-English bilingual children aged 5-6 years who were attending English kindergartens or international institutes participated in this study. Subjects were split into two equal groups, training and control groups. The training group completed intensive working memory training (10 sessions over 2 weeks) which consisted of word span backward training and dual-load condition training tasks. Two groups were assessed on 10 measures of phonological awareness (syllable, phoneme), word recognition (real-word, non-word) and working memory (non-word repetition, Korean Competing Language Processing Task [CLPT], English CLPT) before and after working memory training. Results: The training group showed significant increases in the percentage of correct responses on syllable awareness, phoneme awareness, non-word recognition, forward and backward non-word repetition tasks, but not on real-word recognition, Korean CLPT, and English CLPT tasks. There were no significant differences in all measures between pre-test and post-test in the control group. Conclusion: These results show that linguistic working memory training boosts performance on measures of reading-related skills and working memory. This finding suggests that working memory training could be considered as a reading skill intervention for bilingual children.

Keywords: Preschool bilinguals, Verbal working memory training, Phonological awareness, Word recognition, Non-word repetition, Competing Language Processing Task 작업기억(working memory)은 자극된 정보의 일시적인 저장과 처리에 관여하는 다각적 인지체계로 언어의 학습과 실행 및 학문의 습득에 중요한 역할을 담당한다(Cowan, Nugent, Elliott, Ponomarev, \& Saults, 1999; Unsworth \& Engle, 2007). 언어발달 연구들 은 작업기억이 언어의 음운과 형태적, 문법적 구조 및 이해에 필요 한 복잡한 인지적 처리를 수행하며 정상 아동 및 다양한 형태의 언 어장애 아동의 언어능력과 밀접한 관련이 있음을 보고하였다(Bishop, 1992; Ellis Weismer, Evan, \& Hesketh, 1999; Gathercole \& Alloway, 2006; Montgomery, Magimairaj, \& Finney, 2010; Williams,
Goldstein, \& Minshew, 2006). 또한 작업기억은 추론, 문제해결과 같은 상위인지 과제와 읽기, 쓰기, 수학 등의 학업적 성취에서 개인 차를 설명해 주는 요인으로 제시하였다(Alloway, Gathercole, Kirkwood, \& Elliott, 2009; Just \& Carpenter, 1992; Nation, Adams, Bowyer-Crane, \& Snowling, 1999; Smith-Spark \& Fisk, 2007; Swanson \& Jerman, 2007). 이러한 높은 상관성을 토대로 최근 작업기억 용량이 낮은 개인이 작업기억훈련을 통해 언어와 학업적 성취 및 일상생활에서의 인지적 향상을 증명하는 연구들이 이어지고 있다 (Alloway, Bibile, \& Lau, 2013; Brehmer, Westerberg, \& Bäckman, 
2012; Holmes, Gathercole, \& Dunning, 2009; Kim \& Yim, 2015; Klingberg, 2010; Morrison \& Chein, 2011; Seo \& Kim, 2014).

Baddeley와 Hitch (1974)가 처음 제안한 작업기억모델은 음운루 프(phonological loop), 시공간 스케치패드(visuospatial sketch$\mathrm{pad})$, 중앙집행기(central executive)의 세 가지 구성요소로 이루어 져 있으며 음운루프와 시공간 스케치패드는 저장에 관여하는 특 정영역으로, 중앙집행기는 일반적 영역으로 정의하였다. 음운루프 는 음운 단기기억으로 음운 리허설(phonological rehearsal) 과정을 통해 단기적으로 정보를 저장하고, 시공간 스케치패드는 시공간적 정보를 처리하며, 중앙집행기는 음운루프와 시공간 스케치패드를 모두 관장하면서 정보의 집중 및 전환, 억제와 같은 총체적인 인지 기제의 역할을 담당한다. 이후 Baddeley (2000)는 일화적 완충장치 (episodic buffer)를 추가하여 네 가지 요소로 작업기억을 구성하고 일화적 완충장치가 장기기억체계와 상호작용하면서 음운루프와 시공간 스케치패드, 장기기억 간의 실시간 소통에 기여한다고 설명 하였다. 작업기억용량(working memory capacity)은 한 개인이 작 업기억을 측정하기 위한 과제를 수행할 때 유지할 수 있는 최대 정 보량으로(Conway, Cowan, Bunting, Therriault, \& Minkoff, 2002), 작업기억훈련은 과제 수행을 통해 작업기억용량의 향상을 목표로 한다. 작업기억훈련은 일반적 영역의 작업기억 기제를 훈련하는 것 을 목표로 그와협응된 각 특정 영역의 효과를 높이고자 하는 중앙 집행기 훈련과 작업기억의 특정 영역의 훈련 과제들을 조합하여 사용하는 다중 요소 훈련으로 나눠진다(Morrison \& Chein, 2011). 작업기억훈련에서 자주 사용되는 복잡한 폭 과제(complex span task), 연속적 폭 과제(working memory updating), dual n-back 과 제 등은 일반적 영역인 작업기억의 집행적 기능을 훈련함으로써 작 업기억용량을 높이는 데 초점을 맞추고 있다.

작업기억훈련으로 개발된 대표적인 프로그램으로는 Klingberg program (Klingberg, Forssberg, \& Westerberg, 2002)과 CogMed (Klingberg et al., 2005), Jungle Memory (Alloway \& Alloway, 2008), n-back training (Jaeggi, Buschkuehl, Jonides, \& Perrig, 2008)이 있 다. 먼저, Klingberg program은 $\mathrm{ADHD}$ 아동의 작업기억 향상을 주목적으로 시공간 작업과제, 후진 수 폭 과제, 글자 폭 과제, 선택 반응시간 등의 과제와 반응시간 go/no-go 과제를 혼합하여 총 4 개 의 작업기억과제로 구성되어 있다. Klingberg 등(2002)의 ADHD 아동 연구에서 5 주간의 훈련 뒤 직접적으로 훈련하지 않은 시공간 작업기억 과제와 Raven의 행렬 과제(Raven's colored progressive matrices, 비언어적 추론과제) 수행에 증진을 보인 것으로 나타났 다. 두 번째, CogMed는 Klingberg program을 보다 확장하여 상용 화시킨 프로그램으로 $\mathrm{ADHD}$ 아동과 학습장애를 겪는 아동은 물
론 정상 아동과 성인까지 작업기억 향상을 위해 사용되는 프로그 램으로 시공간 작업기억과 언어작업기억 향상과 관련된 총 8 가지 훈련 과제를 포함한다. $\operatorname{CogMed}$ 를 이용한 연구는 작업기억훈련을 통해 작업기억용량이 증가하고, 학업 성취, 주의 통제 수준이 증가 하는 등의 효과를 보인다고 보고하였다(Brehmer et al., 2011; Brehmer et al., 2012; Seo \& Kim, 2014). 세 번째, Jungle Memory는 AD$\mathrm{HD}$, 난독증, 자폐증, 운동장애, 학습장애를 대상으로 7-16세 아동 및 청소년의 작업기억 향상을 돕는 프로그램이다. 언어적 작업기억 향상, 시공간 작업기억 향상, 주의 통제와 집행적 작업기억 향상을 목표로 하며 Jungle Memory 훈련을 사용한 연구에서 주 4회 훈련 받은 실험집단이 주 1 회 훈련받은 통제집단보다 언어적 작업기억, 시공간 작업기억 및 철자와 산술 관련 검사에서 유의한 향상이 있 는 것으로 나타났다(Alloway et al., 2013). 끝으로, n-back 과제는 피험자들에게 일련의 자극을 일정한 간격을 두고 제시하고, 현재 제시된 자극에서 $\mathrm{n}$ 번째 전에 제시된 자극을 답하는 방식으로 진행 된다. 이 훈련은 작업기억의 집행기능을 향상시키거나 유동지능 (fluid intelligence, 새로운 영역에서 추리하고 문제를 해결할 수 있 는 능력; Cattell, 1943)으로 전이 효과를 기대하는 연구에서 주로 사 용하였다(Jaeggi, Buschkuehl, Perrig, \& Meier, 2010).

두 가지 이상의 언어를 꾸준히 사용하는 이중언어아동들(bilinguals)의 인지능력과 언어능력은 높은 상관관계를 보인다. 이중언 어환경이 아동의 언어 및 인지발달에 미치는 영향을 바라보는 관 점은 크게 두 가지로, 이중언어 사용이 모국어 발달 또는 인지 발달 에 부정적인 영향을 준다는 감가적 이중언어주의(subtractive bilingualism)와 인지발달에 긍정적인 영향을 준다는 부가적 이중언 어주의(additive bilingualism)로 나뉜다(Landry \& Allard, 1991). 감가적 이중언어주의에 따르면 어린 시기에 이중언어를 사용하는 것은 오히려 모국어의 발달을 저해하여 이중언어아동의 어휘력이 단일언어아동에 비해 낮게 나타난다고 하였다(Bialystok, Craik, \& Luk, 2008). Wong Fillmore (1991a, 1991b)는 제2언어(영어)로 의사 소통이 이루어지는 소수민족 아동들의 모국어 능력이 현저히 낮고 가정에서 부모와의 의사소통에도 문제가 발생한다고 보고하였다. 한국어-영어 이중언어 연구(Hwang \& Hwang, 2000) 또한 4-6세의 한국어-영어 이중언어아동(한국어가 모국어로 유치원 또는 학교 에서 영어를 사용하고 가정에서는 한국어를 사용하는 아동)이 한 국어 단일언어아동보다 한국어 어휘력이 크게 떨어짐과 동시에 영 어 단일언어아동보다 영어 어휘력도 크게 떨어진다고 보고하였다. 동일한 맥락에서, Hong과 Yim (2014)의 연구는 정상언어발달을 보 이는 5-7세의 한국어-영어 이중언어아동이 한국어 어휘력과 영어 어휘력 간에 정적 상관을 보이며 특히 영어 어휘력이 비언어성 작업 
기억능력과 유의한 정적 상관을 보인다고 보고하였다. 또한, 6-9세 의 한국어-영어 이중언어아동의 한국어 어휘력은 비언어성 작업기 억뿐만 아니라 언어성 작업기억(한국어)과도 유의한 상관을 보였 다(Yim, Jo, Han, \& Seong, 2016). 이러한 결과는 이중언어 사용의 효능성이 비언어적인 능력과 작업기억 능력에 의존한다는 선행연 구(Brown \& Hulme, 1992)를 지지하며 이중언어아동의 모국어 능 력과 제 2 언어능력이 높을수록 작업기억능력도 함께 높다고 제안 하였다. 반면, 부가적 이중언어주의 관점의 연구에서는 이중언어아 동의 구문능력이 서로 다른 언어의 구문체계를 자유롭게 사용한 다는 점에서 언어 사용 및 발달에 긍정적인 영향을 주고(Meisel, 1989; Paradis \& Genesee, 1996), 이중언어아동의 억제 기능이 단일 언어아동에 비해 뛰어나므로 상위언어능력을 향상시켜 집행기능 과제에서 높은 수행력을 보인다고 하였다(Bialystok \& Craik, 2010; Hilchey \& Klein, 2011; Morales, Calvo, \& Bialystok, 2013). 또한 이 중언어를 사용하는 아동에게 있어 상위 언어적, 상위 인지적 장점 은 취학전 시기에 이미 나타난다고 제안하였다(Campbell \& Sais, 1995; Diaz, Padilla, \& Weathersby, 1991). 한편, Kohnert와 Windsor (2004)는 언어장애가 없는 이중언어아동은 언어 학습체계나 비 언어적 인지발달에서 단일언어아동과 차이가 없으나 언어적 노출 과 같은 외부적 요인의 영향으로 표준화된 언어검사에서 불이익을 받을 수 있으므로 인지처리 평가가 함께 고려되어야 한다고 주장하 였다. 이를 통해 언어는 경험에 의한 지식적인 측면이 아닌 인지적 인 측면에서의 평가가 중요함을 강조하였다.

학자에 따라 둘 이상의 언어를 학습하는 것이 언어와 인지발달 에 긍정적인 효과를 낳는지에 대한 의견은 대립하지만, 이중언어를 구사하는 아동이 단일언어아동에 비해 인지나 상위 언어 등에서 더 높은 수행력을 보인다는 연구 자료(Bialystok \& Majumder, 1998; $\mathrm{Diaz}, 1985)$ 에 근거하여 이중언어아동과 단일언어아동의 작업기억 능력에 대한 연구는 지속적으로 진행되고 있다(Bialystok \& Craik, 2010; Campbell \& Sais, 1995). 이에 반해, 국내에서 조기 영어교육 에 대한 뜨거운 열풍으로 전국의 영어유치원에 3 만 명이 넘는 원생 들이 등록되어 있음에도 불구하고(Ministry of Education, 2016), 한국어-영어 이중언어아동의 언어 및 인지발달에 대한 실질적인 연구는 현재까지 매우 미비한 실정이다. 국내 이중언어아동은 가정 에서 모국어를 경험하고 사회나 교육기관에서 영어에 노출된다는 점에서 해외의 선행연구와 유사하나, 국내에 거주하는 이중언어아 동은 모국어를 포함하여 가정 및 지역 사회에서 통용되는 우세 언 어 또한 영어가 아닌 한국어라는 점에서 상이하다. 더욱이 모국어 보다 제 2 언어가 더 뛰어난 해외 이중언어아동과 달리 국내에서 제 한된 시간에 제 2 언어인 영어를 학습하는 한국어-영어 이중언어아
동의 작업기억에 대한 연구는 거의 알려지지 않았다. 또한, 이중언 어아동의 수가 증가함에 따라 단일언어아동의 언어검사를 목적으 로 만들어진 표준화 검사만으로 이중언어아동의 언어를 과소평가 할 수 있다는 우려가 커지고 있다. 특히 Montgomery (2002)는 아 동의 언어 수행은 작업기억능력에 영향을 받기 때문에 언어 평가 시 표준화된 언어검사 외에 작업기억검사도 함께 포함하여야 함을 주장하였다. 이러한 측면에서 이중언어를 습득하는 아동의 언어발 달과 문화적인 특성을 고려하여 작업기억과 같은 인지처리 과제를 평가 및 훈련 중재로 제안할 수 있겠다.

특히 작업기억에 의한 정보의 조작 및 처리의 역동적인 인지활동 은 학업성취에 깊이 관여하며(Kyllonen \& Christal, 1990), 학습에 필수적인 읽기 기술과도 유의한 상관을 보인다(Smith-Spark \& Fisk, 2007; Swanson \& Jerman, 2007). 난독증 연구에서 개인의 낮 은 언어적 작업기억(verbal working memory)은 단어재인 및 읽기 이해 문제와 밀접한 관련이 있으며(Jacobson et al., 2011; Swanson \& Berninger, 1995; Swanson \& Jerman, 2007), 난독증 아동이 시공 간적 작업기억(visual-spatial WM)보다 언어적 작업기억 과제에서 더 큰 취약함을 보인다고 보고하였다(Papadopoulos, Charalambous, Kanari, \& Loizou, 2004; Siegel \& Ryan, 1989; Vellutino, Scanlon, \& Spearing, 1995). 또한, 이들 결과를 지지하며 Yang, Peng, Zhang과 Mo (2017)는 음운론적 작업기억훈련이 난독증 아동의 음운인식 능력을 향상시킨다고 보고하였다.

본 연구는 한국어-영어 이중언어아동들의 모국어와 제 2 언어, 언 어성 및 비언어성 작업기억 간의 유의한 상관과함께 작업기억과 읽 기 기술의 높은 상관을 보고한 선행연구들에 기초하여 국내에 거 주하는 5-6세의 학령전기 한국어-영어 이중언어아동을 대상으로 읽기와 보다 더 밀접한 언어성 작업기억의 훈련이 음운인식과 단어 재인 및 작업기억 과제의 수행력에 미치는 효과를 알아보고자 하 였다. 본 연구의 세부적인 연구질문은 다음과 같다.

첫째, 학령전기 한국어-영어 이중언어아동집단 간(작업기억훈 련 집단 vs. 비훈련 집단) 사전 및 사후 평가에서 음운인식 과제(음 절, 음소) 수행력에 유의한 차이가 있는가?

둘째, 학령전기 한국어-영어 이중언어아동집단 간(작업기억훈 련 집단 vs. 비훈련 집단) 사전 및 사후 평가에서 단어재인 과제(의 미단어, 무의미단어) 수행력에 유의한 차이가 있는가?

셋째, 학령전기 한국어-영어 이중언어아동집단 간(작업기억훈 련 집단 vs. 비훈련 집단) 사전 및 사후 평가에서 작업기억과제(비단 어 따라말하기, 한국어 문장 폭 기억, 영어 문장 폭 기억) 수행력에 유의한 차이가 있는가? 


\section{연구방법}

\section{연구대상}

본 연구는 서울 및 경기 지역에 거주하고 언어발달이 정상범주 에 속하는 만 5-6세의 한국어-영어 이중언어아동 22명을 연구대상 자로 하여 언어성 작업기억훈련 집단에 11 명, 비훈련 집단에 11 명의 아동을 각각 배치하였다. 이중언어아동의 선정 기준은 (1) 국내 또 는 국외(1명: 출생 후 11 개월에 귀국)에서 출생하여 한국어를 모국 어로 사용하며 3 세 이후에 영어를 습득한 순차적 이중언어아동으 로(Kohnert, 2010), (2) 가정에서 형제 또는 부모(또는 부모 중 한 명)와 고정적으로 한국어를 사용하고, (3) 영어유치원 또는 국제교 류기관에 재학하여 하루에 평균 5 시간 이상, 전체 2 년 이상 영어에 노출되고(Yim et al., 2016), (4) 한국 카우프만 아동용 지능검사 (Korean Kaufman Assessment Battery for Children-II, K-ABC-II; Moon, 2014)에서 동작성 지능 표준점수가 85점(-1 SD) 이상에 속 하며, (5) 수용·표현어휘력검사(Receptive and Expressive Vocabulary Test, REVT; Kim, Hong, Kim, Jang, \& Lee, 2009)와 Peabody Picture Vocabulary Test-IV (PPVT-IV; Dunn \& Dunn, 2007)에서 한국어와 영어를 함께 제시(REVT는 한국어로 먼저 질문하고 답 을 못하면 영어로 질문, PPVT-IV는 영어로 먼저 질문하고 답을 못 하면 한국어로 질문)하여 두 검사 모두에서 수용어휘력 점수가 해 당 연령 규준에서 -1 SD 이상에 해당되고, (6) 한국어로 번안된 알 버타 언어 및 발달 설문지(Alberta Language and Development Questionnaire, ALDeQ; Paradis, Emmerzael, \& Duncan, 2010)에 서 총점이 0.69점(-1 SD) 이상에 속하고, (7) 신체, 감각, 정서, 행동 등의 기질적 문제를 동반하지 않는 아동들로 선별하였다. 전체 22 명의 연구대상자 중 훈련에 동의한 아동은 훈련 집단 $(\mathrm{N}=11)$ 에, 아 동 또는 부모가 훈련을 원치 않거나 시간관계상 훈련 참여가 불가 한 아동은 비훈련 집단 $(\mathrm{N}=11)$ 에 배치하였다. 두 집단은 모두 초등 학교에 입학하지 않은 미취학 아동들로 훈련 집단은 남아 4 명과 여 아7명, 비훈련 집단은 남아6명과 여아 5명으로 구성하였다.

본 연구에 참여한 훈련 집단 이중언어아동의 생활연령 평균은 77 개월(6세 5 개월, $\mathrm{SD}=6.86$ )이며 REVT의 수용어휘 평균은 70.91 점 $(\mathrm{SD}=14.37)$ 으로 7세 1 개월의 등가연령에 해당하여 평균 생활연 령보다 높은 수용어휘능력을 보였고, PPVT-IV의 수용어휘 평균 은 152.91 점 $(\mathrm{SD}=33.38)$ 으로 10 세 2 개월의 등가연령에 해당하여 평균 생활연령보다 높은 수용어휘능력을 보였다. K-ABC-II의 동 작성 지능 표준점수 평균은 126.91 점 $(\mathrm{SD}=15.76)$, 알버타 언어 및 발달 지수 평균은 0.87 점 $(\mathrm{SD}=0.07)$ 으로 모두 정상범주에 속하였 다. 비훈련 집단 이중언어아동의 생활연령 평균은 76 개월(6세 4 개
월, $\mathrm{SD}=8.70)$ 이며 REVT의 수용어휘 평균은 72.82 점 $(\mathrm{SD}=11.92)$ 으로 7세 4 개월의 등가연령에 해당하여 평균 생활연령보다 높은 수용어휘능력을 보였고, PPVT-IV의 수용어휘 평균은 127.55점 $(\mathrm{SD}=27.15)$ 으로 8 세의 등가연령에 해당하여 평균 생활연령보다 높은 수용어휘능력을 보였다. K-ABC-II의 동작성 지능 표준점수 평균은 129 점 $(\mathrm{SD}=12.03)$, 알버타 언어 및 발달 지수 평균은 0.84 점 $(\mathrm{SD}=0.11)$ 으로 모두 정상범주에 속하였다. 집단 간 대상자 특성의 차이를 살펴보기 위하여 독립표본 $t$-검정(independent samples $t$ test)을 실시한 결과, 두 집단은 생활연령 $(t=.30, p=.768)$ 및 REVT 의 수용어휘 $(t=-.34, p=.738)$, PPVT-IV의 수용어휘 $(t=1.96, p=$ $.065), \mathrm{K}-\mathrm{ABC}-\mathrm{II}$ 의 동작성 지능 표준점수 $(t=-.35, p=.730)$, 알버타 언어 및 발달 지수 $(t=.81, p=.428)$ 에서 모두 통계적으로 유의한 차 이를 보이지 않았다. 이때 독립표본 $t$-검정의 $t$ 값은 레벤의 변량동일 성 검정(Leven's test for equality of variance)을 전제로 제시하였고 대상자들의 기본 정보는 Table 1 과 같다.

\section{연구과제 및 절차}

대상자 선별검사

한국 카우프만아동용지능검사(K-ABC-II)

$\mathrm{K}-\mathrm{ABC}-\mathrm{II}$ 는 만 2 세 6 개월과 12 세 5 개월 사이의 아동 및 청소년 의 지능(intelligence)을 임상적으로 평가할 수 있는 개인별 지능검 사도구로, 문화적 차이를 최소화하여 아동이 속해 있는 지역 혹은 사회 계층의 영향을 받지 않고 아동의 능력을 정확하게 평가할 수 있는 범문화적 검사를 지향하고 있다. 본 연구에서 대상자 선정을 위한 기초검사로 $\mathrm{K}-\mathrm{ABC}-\mathrm{II}$ 의 비언어성 검사(손동작, 삼각형, 시각 유추, 위치기억, 사진순서)를 실시하여 동작성 지능지수 85점(-1 $\mathrm{SD})$ 이상을 선정기준으로 하였다.

Table 1. Participants' characteristics

\begin{tabular}{lcccc}
\hline & $\begin{array}{c}\text { WM training } \\
\text { group }(\mathrm{N}=11)\end{array}$ & $\begin{array}{c}\text { Control group } \\
(\mathrm{N}=11)\end{array}$ & $t$ & $p$-value \\
\hline Age (months) & $77.00(6.86)$ & $76.00(8.70)$ & .30 & .768 \\
REVT-R (total score) & $70.91(14.37)$ & $72.82(11.92)$ & -.34 & .738 \\
PPVT-IV (total score) & $152.91(33.38)$ & $127.55(27.15)$ & 1.96 & .065 \\
K-ABC-II (total score) & $126.91(15.76)$ & $129.00(12.03)$ & -.35 & .730 \\
ALDe0 (total score) & $0.87(0.07)$ & $0.84(0.11)$ & .81 & .428 \\
\hline
\end{tabular}

Values are presented as mean (SD).

WM= working memory; REVT-R=Receptive and Expressive Vocabulary Test-Receptive (Kim, Hong, Kim, Jang, \& Lee, 2009); PPVT-IV=Peabody Picture Vocabulary Test fourth edition (Dunn \& Dunn, 2007); K-ABC-II=Korean Kaufman Assessment Battery for Children second edition (Moon, 2014); $\mathrm{ALDeO}=$ Alberta Language and Development Questionnaire (Paradis, Emmerzael, \& Duncan, 2010). 


\section{수용어휘력검사(REVT, PPVT-IV)}

이중언어아동의 모국어와 영어 수용어휘능력을 평가하기 위하 여 REVT와 PPVT-IV를 함께 실시하였다. 이중언어아동의 언어능 력을 한 가지 언어로만 평가할 경우 아동의 언어능력이 과소평가될 수 있으므로(Kayser, 1995; Langdon, 1992) 한국어 어휘력 과제와 영어 어휘력 과제를 실시하여 합산 점수법(conceptual scoring, 한 국어와 영어를 모두 제시하여 두 언어 모두에서 오반응한 것을 틀 린 것으로 간주하여 원점수를 산출하는 방법)을 사용하여 두 검사 규준에서 각각 -1 SD 이상을 선정기준으로 하였다(REVT: 해당 연 령 규준에서 -1 SD 이상; PPVT-IV: 해당 연령의 standard score가 85 점[-1SD] 이상). 한국어와 영어단어 번역에 사용된 사전은 대상 자가 학령전 아동임을 고려하여 DK Children's Illustrated Dictionary (Mcilwain, 2009)와 동아프라임 한영사전(Doosan Donga, 2003)을 참고하여 번역하였다.

알버타 언어 및 발달 설문지(ALDeQ)

$\mathrm{ALDeQ}$ 는 학령전기 아동의 언어 및 발달을 부모 보고를 통해 평 가할 수 있는 검사도구로, 특정 언어 및 문화적 배경에 국한되지 않 고 영어를 학습하는 학령전기 아동에게 실시 가능하며, 정상 발달 과 언어발달 지체 아동을 선별하기 위한 보충검사로 유용하다(Restrepo, 1998). 본 연구에서 한국어로 번안한 Hong과 Yim (2014)의 알버타 언어 및 발달 설문지를 사용하였고, 설문지를 번안 및 재구 성한 Han과 Yim (2018)의 부모보고형 아동 언어능력 평가도구를 함께 참조하였다. $\mathrm{ALDeQ}$ 의 지수 계산법에 따라 0.69점(-1 SD) 이 상을 선정기준으로 하였다.

\section{사전사후 실험 과제}

학령전기 이중언어아동의 언어성 작업기억훈련이 초기 읽기 기 술 및 작업기억에 미치는 영향을 알아보고자 음운인식검사, 단어 재인검사 및 작업기억검사를 실시하였다. 음운인식검사는 음절과 음소인식 과제를 포함하였고, 단어재인검사는 의미와 무의미단어 읽기 과제를 포함하였다. 작업기억검사는 비단어 따라말하기와 문 장 폭 기억 과제, 작업기억훈련의 일반화를 확인하기 위한 영문 문 장 폭 기억 과제를 실시하였다.

\section{음운인식 과제}

음운인식 과제는 음절과 음소의 변별, 생략, 합성, 분절 과제로 구 성하였다. 현재 제작 중인 한국아동언어처리능력평가(Korean Language Processing Assessment for Children, KOLPAC; Kim, in press)의 변별 과제 중 초성과 종성이 반복되는 문항을 제외하고 8
개의 문항을 변별 과제(음절 4 문항, 음소 4 문항)로 사용하고, Kim (2016)의 연구에서 사용된 생략, 합성, 분절 과제에서 각각 8 문항 (음절 4 문항, 음소 4 문항씩)을 사용하였다. 생략과 분절 과제는 종 성 유무에 따라 고르게 문항을 선택하고, 합성 과제에서는 2음절 과 3 음절 단어를 사용하였다. 전체 32 문항으로 구성된 음운인식검 사는 음절인식 16 문항, 음소인식 16 문항으로, 각 문항을 음성으로 녹음하여 아동이 컴퓨터에서 들리는 질문을 듣고 벨소리 뒤에 답 하도록 지시하였다.

\section{단어재인 과제}

$\mathrm{Je}$ (2014)의 연구에서 사용된 단어재인 과제를 실시하였다. 전체 40 문항으로 의미단어 20 문항, 무의미단어 20 문항으로 구성되며, 각 20 문항은 2 음절 10 문항(받침없는 단어와 받침있는 단어가 각각 5 개씩), 3 음절 10 문항(받침없는 단어와 받침있는 단어가 각각 5 개 씩)을 포함한다. 검사항목의 제시방법은 Je (2014)의 연구와 동일한 순서로 의미단어와 무의미단어를 무작위로 섞어 2음절 받침없는 단어 10 문항, 2 음절 받침있는 단어 10 문항, 3 음절 받침없는 단어 10 문항, 3 음절 받침있는 단어 10 문항을 순차적으로 컴퓨터 화면에 한 단어씩 제시하고 아동이 소리 내어 읽도록 지시하였다.

\section{비단어 따라말하기 과제}

Lee, Kim과 Yim (2013) 연구에서 사용된 비단어 따라말하기 한 국어 과제를 실시하였다. 비단어 따라말하기 검사는 단어의 모음 과 종성 자음을 그대로 두고 각 음절의 초성 자음들의 위치를 서로 바꾸어 전체 20 문항의 비단어를 제작하여 정순 또는 역순으로 따 라말하도록 하는 검사이다. 각 문항을 음성으로 녹음하여 아동이 컴퓨터에서 들리는 단어를 듣고 벨소리 뒤에 따라말하도록 지시하 고, 정순과 역순 검사(각 20문항) 중 정순 비단어 따라말하기 검사 를 먼저 실시하였다.

\section{문장 폭기억 과제(한국어, 영어)}

한국어 문장 폭 기억용량을 측정하기 위해 Gaulin과 Campbell (1994)의 Competing Language Processing Task (CLPT)를 수정 보 완한 한국아동언어처리능력평가(KOLPAC)의 문장 폭 기억 과제 를 실시하였다. 이 과제는 문장을 듣고 문장의 진위 여부를 '예/아 니오로 답하는 정오판단과 함께 문장의 첫 단어를 회상하여 산출 하는 검사이다. CLPT는 문장의 마지막 단어를 회상하도록 요구하 는 반면 KOLPAC은 한글 문장 특성상 마지막 단어가 동사 변형 형 태로 답하는 경우가 발생하므로 명사로 답변 가능한 문장의 첫 단 어를 회상하도록 요구한다. 검사의 난이도는 1 문장이 제시되는 1 단 
계에서 6 문장이 제시되는 6 단계로 구성되며 1단계는 1 문항을, 2 단 계에서 6단계는 각 단계마다 2 세트씩 전체 41 문장을 검사하였다 (예를 들어, 3 단계는 3 문장이 1 세트로 제시되고 2세트씩 검사가 진 행되어 제시되는 문장 수는 모두 6).

이중언어를 사용하는 아동에게 한국어 작업기억훈련의 효과가 영어 문장 폭 기억 과제에도 일반화가 나타나는지 확인하고자 Gaulin과 Campbell (1994)의 CLPT를 실시하였다. 영어 문장 폭 기억 과제는 한국어 문장 폭 기억 과제와 동일한 난이도(1단계에서 6단 계)로 구성되나 아동에게 문장을 들려주고 문장의 진위 여부를 'True/False'로 답하게 하고 문장의 첫 단어가 아닌 마지막 단어를 회상 산출하도록 요구하였다. 1단계에서 6단계까지 단계마다 2세 트씩 전체 42 문장을 검사하고 한국어와 영어 문장 폭 기억검사 모 두 녹음된 음성파일을 사용하여 검사를 진행하였다.

\section{언어성 작업기억훈련 과제}

작업기억용량을 증진시키기 위하여 2가지 언어성 작업기억 과제 를 훈련하였다. 저장 및 처리가 동시에 요구되는 역순 단어 폭 훈련 과제와 인지적으로 더 많은 집중과 처리를 필요로 하는 이중-처리 작업조건(dual-load condition; Montgomery, 2000a, 2000b) 훈련 과제를 실시하였다.

\section{역순 단어 폭작업기억훈련}

단어 폭 훈련자극은 Han, Seung과 Choi (2016)의 연구에서 조사 한 0-5세의 고빈도 동물명사를 사용하였고, 추가로 어린이용 동물 플래시 카드와 팝업북, 서울대공원 어린이 동물원에 있는 동물목 록을 참조해 2 음절의 동물명사 22 개를 훈련자극으로 선정하였다. 역순 단어 폭 훈련은 제 1 연구자가 개발한 애플리케이션을 통해 아 동이 청각적으로 제시한 단어를 듣고 제시한 순서와 반대로 말하 도록 요구하였다. 훈련의 난이도 설정은 Kim과 $\operatorname{Yim}$ (2015)의 연구 와 Lee, Hong, Shin과 Kim (2015)의 연구에서 제시한 집행기능훈 련 과제의 단계별 난이도 조절 전략 절차를 따르되, 최소 단어 폭이 2 개로 구성된 1단계에서 최대 단어 폭이 7 개로 구성된 6단계로 설 정하였다. 각 훈련 단계에서 단어들의 조합은 22 개 명사를 무작위 로 선정하여 훈련항목을 구성하였다. 응답시간은 10 초로 제한하고 시간이 초과하면 오반응으로 간주하였으며 각 단계에서 훈련 수행 은 5 회로 제한하였다. 단, 1 단계는 훈련 수행 횟수에 제한을 두지 않 았다. 5 회 중 3 회 연속적으로 정반응이 나타나면 상위 단계로 이동 하고 그렇지 않으면 이전 단계로 이동하여 훈련을 진행하였다. 1 회 기 훈련의 목표는 최소 시작단계 +1 로 마무리되도록 하고 훈련시간 은 10 분으로 제한하였다. 전체 훈련기간은 2 주 동안 10 회기의 훈련
이 진행되었다. 단어 폭 훈련에 사용된 동물단어 목록은 Appendix 1 에 제시하였다.

이중-처리작업조건훈련

Han 등(2016)의 연구에서 조사한 0-5세의 고빈도 사물단어와 어린이용 사물 인지 플래시 카드에 나오는 단어를 추가하여 5 가지 의미범주(옷, 신체, 탈 것, 동물, 과일)에 각각 5 개의 단어를 배치하 여 훈련자극으로 선정하였다. 훈련단어는 모두 2 음절로 제한하고 동물범주에는 단어 폭작업기억훈련에서 사용된 동물단어를 제외 하였다. 이중-처리 작업조건훈련은 제 1 연구자가 개발한 애플리케 이션을 통해 1 단계에서 3 개의 단어조합을, 5 단계에서 7 개의 단어조 합을 아동에게 들려주고 먼저 같은 범주에 들어갈 단어를 말한 뒤 그 범주 안에 들어간 단어를 작은 크기에서 큰 크기 순서로 답하도 록 요구하였다. 예를 들어, 1 단계에서 3 개의 단어 '나비, 사과, 거위' 를 듣고 아동은 '나비 $\rightarrow$ 거위 $\rightarrow$ 사과' 또는 '사과 $\rightarrow$ 나비 $\rightarrow$ 거위’로 답하 도록 요구하였다. 각 훈련 단계에서 단어들의 조합은 무작위로 선 정하여 2 개의 의미범주를 내포하도록 구성하였다. 훈련을 시작하 기 전 아동이 훈련방법을 완전히 이해하도록 단어자극을 컬러 사 진(A4용지 $1 / 4$ 크기)으로 제시하고 아동이 직접 단어를 각 범주에 분류한 뒤 각 범주에서 물리적 크기가 작은 것부터 큰 것으로 재배 치하도록 연습하였다. 아동이 훈련자극에 대해 충분히 이해한 후 1 회기 훈련을 진행하였다. 훈련 과정은 역순 단어 폭 작업기억훈련 과 동일한 형태로 응답시간을 10 초로 제한하고 시간이 초과하면 오반응으로 간주하였으며 각 단계에서 훈련 수행은 5 회로 제한하 였다. 1단계는 훈련 수행 횟수에 제한을 두지 않았고, 각 훈련 단계 에서 5 회 중 3 회 연속적으로 정반응이 나타나면 상위 단계로, 그렇 지 않으면 이전 단계로 이동하여 훈련을 진행하였다. 1 회기 훈련의 목표는 최소 시작단계 +1 로 마무리되도록 하고 훈련시간은 10 분으 로 제한하였다. 전체 훈련기간은 2 주 동안 10 회기의 훈련이 진행되 었다. 이중-처리 작업조건훈련에 사용된 의미범주별 단어목록은 Appendix 2에 제시하였다.

\section{연구 절차}

이중언어아동을 대상으로 언어성 작업기억훈련이 음운인식 및 단어재인, 작업기억능력을 향상시키는지 알아보기 위하여 훈련 집 단과 비훈련 집단으로 나누어 훈련 효과를 사전사후로 비교하여 검증하였다. 모든 검사와 훈련은 아동의 집에서 개별적으로 실시하 였고 사전 및 사후 평가는 훈련 전 2-3일, 훈련 후 2-3일 간격을 두고 실시하였다. 작업기억훈련은 2주 동안 월요일에서 금요일까지 주 5 회로 총 10 회기를 진행하였고, 한 회기에 역순 단어 폭 작업기억훈 
련 10 분, 이중-처리 작업조건훈련 10 분으로 전체 20 분의 훈련시간 을 적용하였다. 작업기억훈련은 제 1 연구자, 1 인이 모두 실시하여 훈 련방법 적용에 있어 훈련자 간 차이는 없으며, 훈련자가 매 회기 작 업기억훈련 전 아동이 애플리케이션 사용과 훈련방법을 정확히 이 해하는지 확인하고 훈련이 시작된 이후에는 특별한 도움이나 단서 제공 없이 훈련의 단계별 난이도 조절 절차에 따라 훈련을 진행하 고 아동의 반응을 기록하였다.

\section{자료 분석}

작업기억훈련 전후의 음운인식 및 단어재인, 작업기억검사의 정 확도는 모두 정반응률(\%)로 측정하였다. 음운인식검사는 음절인 식 16 문항, 음소인식 16 문항으로 각 문항에 대해 정반응한 경우 1 점으로 평가하여 음절인식과 음소인식의 정반응률(\%)을 각각 계 산하였다. 단어재인검사 또한 의미단어, 무의미단어 검사에서 20 문 항씩 정반응한 문항을 1 점으로 평가하여 각각의 정반응률(\%)을 계산하였다. 비단어 따라말하기 검사는 정순과 역순 검사에서 각 각 20 문항씩 정반응한 문항을 1 점을 평가하여 각각의 정반응률 (\%)을 계산하였다. 이때 약한 왜곡과 첨가는 정반응으로, 생략과 대치는 오반응으로 정의하고, 정반응한 후 오류로 다시 반응하는 경우 또는 오반응한 후 다시 정정하여 정반응하는 경우 모두 정반 응으로 간주하였다(Lee, 2010; Yim et al., 2016). 한국어 문장 폭 기 억 과제는 총 41 문항으로 각 문항에 대해 문장의 정오판단에서 정 반응 여부를 평가하고 첫 단어 회상에서 정반응 여부를 평가하여 정오판단과 회상의 정반응률(\%)을 각각 계산하였다. 영어 문장 폭 기억 과제는 총 42 문항으로 한국어 문장 폭 기억 과제와 동일한 방 법으로 정오판단과 회상의 정반응률(\%)을 각각 계산하였다.

\section{신뢰도 및 통계처리}

평가자 간 신뢰도

사전사후 검사의 평가자 간 신뢰도를 검증하기 위하여 전체 22 명 의 피험자 중 무작위로 선택한 5 명 $(23 \%$ 에 해당)의 자료를 바탕으로 연구자 2 인의 평가자 간 신뢰도를 구하였다. 각 검사에서 평가결과가 일치한 문항수를 전체 문항수로 나눈 값에 100 을 곱하여 평가자 간 신뢰도를 산출하였다. 그 결과, 음운인식 과제에서 평가자간 신뢰도 는 음절에서 $100 \%$, 음소에서 $96 \%$, 단어재인 과제에서 평가자간 신 뢰도는 의미단어, 무의미단어 모두에서 $100 \%$ 로 나타났다. 작업기억 과제 중 비단어 따라말하기의 평가자 간 신뢰도는 정순에서 $95 \%$, 역 순에서 $90 \%$ 로 나타났으며 한국어와 영어의 문장 폭 기억 과제의 정 오판단 및 회상에서의 평가자 간 신뢰도는 모두 $100 \%$ 로 나타났다.

\section{통계처리}

언어성 작업기억훈련에 따른 음운인식과 단어재인, 비단어 따라 말하기의 수행력 변화에 대한 훈련 집단과 비훈련 집단 간 차이를 알아보고자 3요인 혼합분산분석(mixed three-factor ANOVA)을 실시하였다. 집단유형을 피험자 간 요인(between subjects factor)으 로, 측정 시기와 과제 유형을 피험자 내 요인(within subjects factor) 으로 하여 각 과제의 정반응률에 대한 분석을 수행하였다. 또한, 한 국어와 영어의 문장 폭 기억 과제의 정오판단과 회상에서 훈련 전 후의 수행력 변화에 대한 집단 간 차이를 확인하고자 2 요인 혼합분 산분석(mixed two-factor ANOVA)을 실시하였다. 집단유형을 피 험자 간 요인으로, 측정 시기를 피험자 내 요인으로 하여 정오판단 과 회상 과제의 정반응률에 대한 분석을 각각 수행하였다. 반복측 정의 통계적 유의성을 알아보기 위해 구형성 검정(Mauchly's sphericity tests)을 실시하였을 때 본 연구의 모든 분석에서 구형성 가정 을 만족하였고, 집단 내 과제 간 유의한 차이는 Cohen's $d$ 를 이용한 효과크기(effect size)를 산출하여 Cohen (1988)의 기준에 따라.8 이상은 큰 효과, .5 는 중간 효과, .2 이하는 작은 효과로 해석하였다. 본 연구의 모든 자료분석은 IBM SPSS statistics version 21.0 프로 그램을 사용하여 분석하였다.

\section{연구결과}

\section{집단 간 음운인식 과제의 수행력 비교}

2가지 음운인식 과제(음절인식, 음소인식)에 대한 사전사후 평가 에서 훈련 집단과 비훈련 집단 간에 유의한 차이가 있는지 살펴보 기 위하여 mixed three-factor ANOVA를 실시한 결과, 측정 시기에 대한 주효과가 통계적으로 유의하여 사전검사보다 사후검사에서 음운 인식의 정반응률이 높게 나타났으며(사전: $\mathrm{M}=73.01, \mathrm{SE}=1.92$; 사후: $\left.\mathrm{M}=80.82, \mathrm{SE}=1.81 ; F_{(1,20)}=17.29, p<.001, \eta_{\mathrm{p}}{ }^{2}=.464\right)$, 음운인 식에 대한 주효과가 유의하여 음소인식보다 음절인식에서 정반응 률이 높게 나타났다(음절인식: $\mathrm{M}=90.77, \mathrm{SE}=1.29$; 음소인식: $\mathrm{M}=$ $\left.63.07, \mathrm{SE}=2.65 ; F_{(1,20)}=109.33, p<.001, \eta_{\mathrm{p}}{ }^{2}=.845\right)$. 또한, 측정 시기 와 집단 간 이차상호작용 $\left(F_{(1,20)}=12.62, p<.01, \eta_{\mathrm{p}}{ }^{2}=.387\right)$ 이 통계적 으로 유의하여 각 집단 내에서 사전사후의 음운인식 정확률을 비 교한 결과, 훈련 집단은 사전사후 간 음운인식에 유의한 차이가 나 는 반면 $\left(t_{(10)}=-7.46, p<.001\right)$, 비훈련 집단은 사전사후간 음운 인식 에 유의한 차이가 나타나지 않았다 $\left(t_{(10)}=-.353, p=.731\right)$. 측정 시기 와 음운인식 간 이차상호작용 $\left(F_{(1,20)}=4.74, p<.05, \eta_{\mathrm{p}}{ }^{2}=.192\right)$ 이 유 의하여 각 음운인식 과제에서 사전사후의 정반응률을 비교한 결 과, 음절인식과 음소인식 모두 사전사후 간에 유의한차이를 보였고 
이 중 음절인식의 차이 $\left(t_{(21)}=-3.04, p<.01\right)$ 가 음소인식 $\left(t_{(21)}=-2.76\right.$, $p<.05)$ 보다 높게 나타났다. 측정 시기와 음운인식, 집단 간 삼차상 호작용 $\left(F_{(1,20)}=18.08, p<.001, \eta_{\mathrm{p}}{ }^{2}=.475\right)$ 이 통계적으로 유의하여 각 집단 내에서 음절과 음소인식의 사전사후의 정반응률을 비교한 결 과, 훈련 집단은 음절과 음소인식 모두에서 사전사후 간에 유의한 차이를 보인 반면(음절인식: $t_{(10)}=-3.63, p<.01 ;$ 음소 인식: $t_{(10)}=$ $-7.36, p<.001)$, 비훈련 집단은 음절과 음소인식 모두에서 유의한 차 이를 보이지 않았다(음절인식: $t_{(10)}=-1.41, p=.190$; 음소인식: $\left.t_{(10)}=.357, p=.728\right)$. 특히 훈련 집단은 음절보다 음소인식에서 사전 사후 간 정반응률의 차이가 크게 나타났으며, 음운인식의 유의한 차이는 effect size가 음소인식(Cohen's $d=2.22$ ), 음절인식(Cohen's $d=1.09$ ) 순으로 매우 큰 것으로 나타났다. 두 집단의 사전사후 평가 에 따른 음운인식 과제의 수행력을 Table 2 와 Figure 1에 제시하였 고, mixed three-factor ANOVA 결과를 Table 3에 제시하였다.

\section{집단 간 단어재인 과제의 수행력 비교}

2 가지 단어재인 과제(의미단어, 무의미단어)에 대한 사전사후 평 가에서 훈련 집단과 비훈련 집단 간에 유의한 차이가 있는지 살펴 보기 위하여 mixed three-factor ANOVA를 실시한 결과, 측정 시기 에 대한 주효과가 통계적으로 유의하여 사전검사보다 사후검사에 서 단어재인의 정반응률이 높게 나타났으며(사전: $\mathrm{M}=89.21, \mathrm{SE}=$

Table 2. Descriptive statistics for WM training and control groups on phonological awareness measures

\begin{tabular}{llllll}
\hline & \multicolumn{2}{c}{ WM training group (N=11) } & & \multicolumn{2}{c}{ Control group (N=11) } \\
\cline { 2 - 3 } \cline { 5 - 6 } & Pre-test & Post-test & & Pre-test & Post-test \\
\hline Phonological awareness $(\%)$ & & & & \\
Syllable & $90.91(6.47)$ & $96.59(5.84)$ & & $85.80(7.95)$ & $89.77(8.04)$ \\
Phoneme & $51.70(15.59)$ & $75.00(12.50)$ & & $63.64(11.46)$ & $61.93(16.41)$ \\
\hline
\end{tabular}

Values are presented as mean (SD) of percentage of correct responses. $\mathrm{WM}=$ working memory.

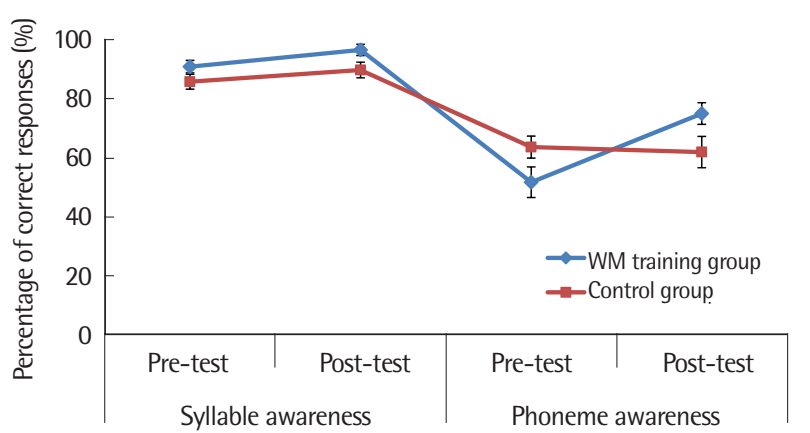

Figure 1. Pre-test and post-test results of working memory (WM) training and control groups on phonological awareness measures.
2.69; 사후: $\left.\mathrm{M}=92.39, \mathrm{SE}=1.99 ; F_{(1,20)}=5.77, p<.05, \eta_{\mathrm{p}}{ }^{2}=.224\right)$, 단 어재인에 대한 주효과가 유의하여 무의미단어재인보다 의미단어 재인에서 정반응률이 높게 나타났다(의미단어재인: $\mathrm{M}=98.07$, $\mathrm{SE}=1.29 ;$ 무의미단어재인: $\mathrm{M}=83.52, \mathrm{SE}=3.47 ; F_{(1,20)}=30.96, p<.001$, $\left.\eta_{\mathrm{p}}{ }^{2}=.608\right)$. 측정 시기와 집단 간 이차상호작용 $\left(F_{(1,20)}=4.97, p<.05\right.$, $\left.\eta_{\mathrm{p}}{ }^{2}=.199\right)$ 이 통계적으로 유의하여 각 집단 내에서 사전사후의 단 어재인 정반응률을 비교한 결과, 훈련 집단은 사전사후 간 단어재 인에 유의한 차이를 보인 반면 $\left(t_{(10)}=-3.36, p<.01\right)$, 비훈련 집단은

Table 3. Summary of mixed three-factor ANOVA on phonological awareness (PA) measures

\begin{tabular}{|c|c|c|c|c|}
\hline & $F(1,20)$ & $p$-value & partial $\eta^{2}$ & Observed power \\
\hline \multicolumn{5}{|l|}{ Main effect } \\
\hline Group & 1.03 & .323 & .049 & .162 \\
\hline Test time & 17.29 & $.000^{* * *}$ & .464 & .977 \\
\hline PA level & 109.33 & $.000^{* * *}$ & .845 & 1.000 \\
\hline \multicolumn{5}{|l|}{ Two-way interaction } \\
\hline Test time $\times$ Group & 12.62 & $.002^{* *}$ & .387 & .922 \\
\hline PA level × Group & 1.04 & .320 & .049 & .163 \\
\hline Test time $\times$ PA level & 4.74 & $.042^{*}$ & .192 & .545 \\
\hline \multicolumn{5}{|l|}{ Three-way interaction } \\
\hline Test time ×PA level × Group & 18.08 & $.000^{* * *}$ & .475 & .981 \\
\hline
\end{tabular}

${ }^{*} p<.05,{ }^{* *} p<.01,{ }^{* * *} p<.001$.

Table 4. Descriptive statistics for WM training and control groups on word recognition measures

\begin{tabular}{ccccccc}
\hline & \multicolumn{2}{c}{ WM training group (N=11) } & & \multicolumn{2}{c}{ Control group (N=11) } \\
\cline { 2 - 3 } & Pre-test & Post-test & & Pre-test & Post-test \\
\hline Word recognition (\%) & & & & \\
Real-word & $98.18(4.62)$ & $100.00(0.00)$ & & $97.27(9.05)$ & $96.82(7.51)$ \\
Non-word & $79.55(12.74)$ & $90.00(5.92)$ & & $81.82(23.48)$ & $82.73(20.29)$ \\
\hline
\end{tabular}

Values are presented as mean (SD) of percentage of correct responses. $\mathrm{WM}=$ working memory.

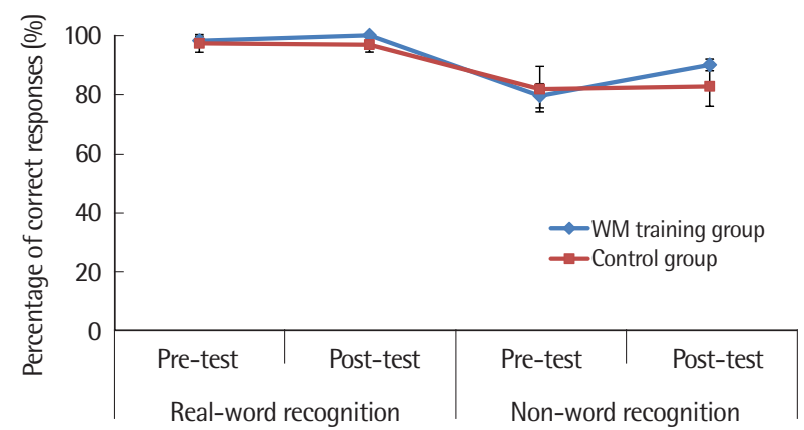

Figure 2. Pre-test and post-test results of working memory (WM) training and control groups on word recognition measures. 
사전사후 간 단어재인에 유의한 차이를 보이지 않았다 $\left(t_{(10)}=-.118\right.$, $p=.908)$. 측정 시기와 단어 재인 간 이차상호작용 $\left(F_{(1,20)}=7.81\right.$, $\left.p<.05, \eta_{\mathrm{p}}^{2}=.281\right)$ 이 유의하여 각 단어재인 과제에서 사전사후의 정반응률을 비교한 결과, 무의미단어재인에서 유의한 차이를 보인 반면 $\left(t_{(21)}=-2.46, p<.05\right)$, 의미단어재인에서는 유의한 차이를 보이 지 않았다 $\left(t_{(21)}=-.826, p=.418\right)$. 두 집단의 사전사후 평가에 따른 단어재인 과제의 수행력을 Table 4와 Figure 2에 제시하였고, mixed three-factor ANOVA 결과를 Table 5에 제시하였다.

Table 5. Summary of mixed three-factor ANOVA on word recognition (WR) measures

$F(1,20) \quad p$-value partial $\eta^{2}$ Observed power

\begin{tabular}{|c|c|c|c|c|}
\hline \multicolumn{5}{|l|}{ Main effect } \\
\hline Group & .25 & .622 & .012 & .076 \\
\hline Test time & 5.77 & $.026^{*}$ & .224 & .627 \\
\hline WR level & 30.96 & $.000^{* * *}$ & .608 & 1.000 \\
\hline \multicolumn{5}{|l|}{ Two-way interaction } \\
\hline Test time $\times$ Group & 4.97 & $.037^{*}$ & .199 & .564 \\
\hline WR level $\times$ Group & .01 & .932 & .000 & .051 \\
\hline Test time $\times$ WR level & 7.81 & $.011^{*}$ & .281 & .757 \\
\hline \multicolumn{5}{|l|}{ Three-way interaction } \\
\hline Test time $\times$ WR level $\times$ Group & 4.13 & .056 & .171 & .490 \\
\hline
\end{tabular}

${ }^{*} p<.05,{ }^{* * *} p<.001$.

Table 6. Descriptive statistics for WM training and control groups on nonword repetition measures

\begin{tabular}{ccccccc}
\hline & \multicolumn{2}{c}{ WM training group (N=11) } & & \multicolumn{2}{c}{ Control group (N=11) } \\
\cline { 2 - 3 } \cline { 5 - 6 } & Pre-test & Post-test & & Pre-test & Post-test \\
\hline Non-word repetition (\%) & & & & \\
Forward & $74.09(11.79)$ & $88.64(7.10)$ & & $75.91(12.00)$ & $71.82(9.29)$ \\
Backward & $27.27(16.03)$ & $50.80(17.91)$ & & $32.18(15.44)$ & $33.64(16.90)$ \\
\hline
\end{tabular}

Values are presented as mean (SD) of percentage of correct responses. WM= working memory.

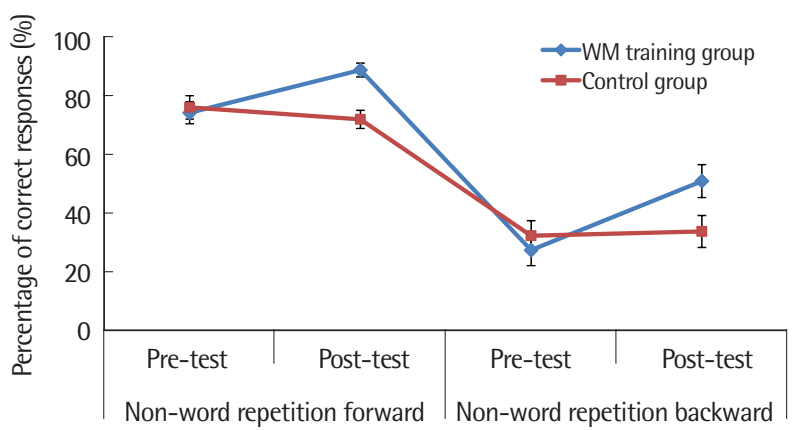

Figure 3. Pre-test and post-test results of working memory (WM) training and control groups on non-word repetition measures.

\section{집단 간 비단어 따라말하기 과제의 수행력 비교}

2가지 비단어 따라말하기 과제(정순, 역순)에 대한 사전사후 평 가에서 훈련 집단과 비훈련 집단 간에 유의한 차이가 있는지 살펴 보기 위하여 mixed three-factor ANOVA를 실시한 결과, 측정 시기 에 대한 주효과가 통계적으로 유의하여 사전검사보다 사후검사에 서 비단어 따라말하기의 정반응률이 높게 나타났으며(사전: $\mathrm{M}=$ $52.36, \mathrm{SE}=2.21$; 사후: $\mathrm{M}=61.22, \mathrm{SE}=2.07 ; F_{(1,20)}=13.60, p<.01$, $\left.\eta_{\mathrm{p}}{ }^{2}=.405\right)$, 비단어 따라말하기에 대한 주효과가 유의하여 역순보 다 정순 비단어 따라말하기에서 정반응률이 높게 나타났다(정순 비단어 따라말하기: $\mathrm{M}=77.61, \mathrm{SE}=1.89$; 역순 비단어 따라말하기: $\left.\mathrm{M}=35.97, \mathrm{SE}=2.93 ; F_{(1,20)}=147.57, p<.001, \eta_{\mathrm{p}}{ }^{2}=.881\right)$. 측정 시기와 집단 간 이차상호작용 $\left(F_{(1,20)}=17.94, p<.001, \eta_{\mathrm{p}}{ }^{2}=.473\right)$ 이 통계적 으로 유의하여 각 집단 내에서 사전사후의 비단어 따라말하기 정 확률을 비교한 결과, 훈련 집단은 사전사후 간 비단어 따라말하기 에 유의한 차이를 보인 반면 $\left(t_{(10)}=-4.40, p<.01\right)$, 비훈련 집단은 사 전사후간 비단어 따라말하기에 유의한차이를 보이지 않았다 $\left(t_{(10)}=\right.$ $.629, p=.544)$. 두 집단의 사전사후 평가에 따른 비단어 따라말하 기 과제의 수행력을 Table 6과 Figure 3에 제시하였고, mixed threefactor ANOVA 결과를 Table 7에 제시하였다.

\section{집단 간 한국어 문장 폭 기억 과제의 수행력 비교}

한국어 문장 폭 기억 과제(정오판단, 회상)에 대한 사전사후 평 가에서 훈련 집단과 비훈련 집단 간에 유의한 차이가 있는지 살펴 보기 위하여 각 과제별로 mixed two-factor ANOVA를 실시하였 다. 정오판단 과제에서 사전사후 간 두 집단의 수행력 차이를 분석 한 결과, 측정 시기에 대한 주효과가 통계적으로 유의하여 사전검 사보다 사후검사에서 정오판단의 정반응률이 높게 나타났다(사전:

Table 7. Summary of mixed three-factor ANOVA on non-word repetition (NWR) measures

\begin{tabular}{|c|c|c|c|c|}
\hline & $F(1,20)$ & $p$-value & partial $\eta^{2}$ & Observed power \\
\hline \multicolumn{5}{|l|}{ Main effect } \\
\hline Group & 3.69 & .069 & .156 & .448 \\
\hline Test time & 13.60 & $.001^{* *}$ & .405 & .939 \\
\hline NWR level & 147.57 & $.000 * * *$ & .881 & 1.000 \\
\hline \multicolumn{5}{|l|}{ Two-way interaction } \\
\hline Test time×Group & 17.94 & $.000^{* * *}$ & .473 & .981 \\
\hline NWR level×Group & .04 & .843 & .002 & .054 \\
\hline Test time $\times$ NWR level & 2.94 & .102 & .128 & .372 \\
\hline \multicolumn{5}{|l|}{ Three-way interaction } \\
\hline Test time ×NWR level×Group & .16 & .689 & .008 & .067 \\
\hline
\end{tabular}


$\mathrm{M}=92.35, \mathrm{SE}=1.44 ;$ 사후: $\mathrm{M}=95.79, \mathrm{SE}=.82 ; F_{(1,20)}=6.19, p<.05$, $\eta_{\mathrm{p}}{ }^{2}=$.236). 이외 집단에 대한 주효과와 측정 시기와 집단 간 이차상 호작용은 모두 통계적으로 유의하지 않았다. 또한, 회상 과제에서 사전사후 간 두 집단의 수행력 차이를 분석한 결과, 집단 및 측정 시 기에 대한 주효과와 측정 시기와 집단 간 이차상호작용 모두 통계 적으로 유의하지 않았다. 두 집단의 사전사후 평가에 따른 한국어 문장 폭 기억 과제의 수행력을 Table 8과 Figure 4에 제시하였고, 정 오판단과 회상의 mixed two-factor ANOVA 결과들을 Tables 9, 10 에각각 제시하였다.

\section{집단 간 영어 문장 폭 기억 과제의 수행력 비교}

영어 문장 폭 기억 과제(정오판단, 회상)에 대한 사전사후 평가에 서 훈련 집단과 비훈련 집단 간에 유의한 차이가 있는지 살펴보기 위하여 각 과제별로 mixed two-factor ANOVA를 실시하였다. 정오 판단 과제에서 사전사후 간 두 집단의 수행력 차이를 분석한 결과, 측정 시기에 대한 주효과가 통계적으로 유의하여 사전검사보다 사 후검사에서 정오판단의 정반응률이 높게 나타났다(사전: $\mathrm{M}=80.41$, $\mathrm{SE}=3.00 ;$ 사후: $\left.\mathrm{M}=89.29, \mathrm{SE}=1.84 ; F_{(1,20)}=15.37, p<.001, \eta_{\mathrm{p}}{ }^{2}=.435\right)$. 이외 집단에 대한 주효과와 측정 시기와 집단 간 이차상호작용은 모두 통계적으로 유의하지 않았으며, 이들 결과들은 한국어 문장

Table 8. Descriptive statistics for WM training and control groups on Korean CLPT measures

\begin{tabular}{ccccccc}
\hline & \multicolumn{2}{c}{ WM training group (N=11) } & & \multicolumn{2}{c}{ Control group (N=11) } \\
\cline { 2 - 3 } \cline { 5 - 6 } & \multicolumn{2}{c}{ Pre-test } & Post-test & & Pre-test & Post-test \\
\hline Korean CLPT (\%) & & & & & \\
True-False & $92.68(7.64)$ & $96.01(1.97)$ & & $92.02(5.78)$ & $95.56(5.09)$ \\
Word-Recall & $47.01(16.86)$ & $48.11(11.34)$ & & $37.47(13.59)$ & $37.03(12.28)$ \\
\hline
\end{tabular}

Values are presented as mean (SD) of percentage of correct responses. WM= working memory; CLPT = Competing Language Processing Task.

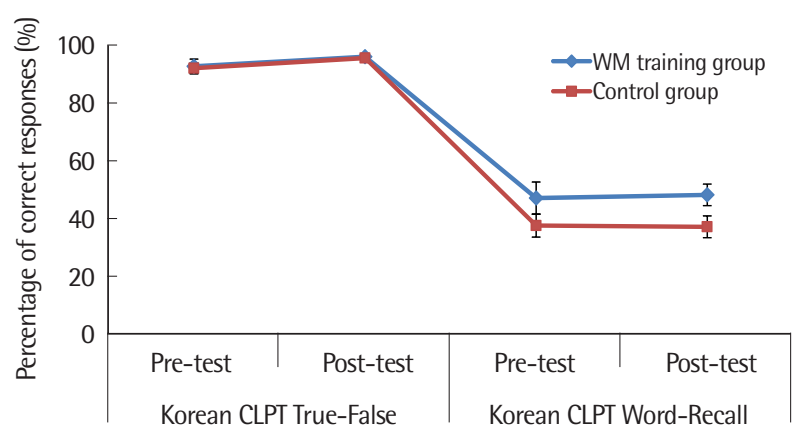

Figure 4. Pre-test and post-test results of working memory (WM) training and control groups on Korean CLPT measures.

CLPT $=$ Competing Language Processing Task.
폭 기억과제의 정오판단 결과와 동일하였다. 또한, 회상 과제에서 사전사후간 두 집단의 수행력 차이를 분석한 결과, 집단 및 측정 시 기에 대한 주효과와 측정 시기와 집단 간 이차상호작용 모두 통계 적으로 유의하지 않아 한국어 문장 폭 기억 과제의 회상 결과와 동 일하였다. 두 집단의 사전사후 평가에 따른 영어 문장 폭 기억 과제 의 수행력을 Table 11과 Figure 5에 제시하였고, 정오판단과 회상의 mixed two-factor ANOVA 결과들을 Tables 12, 13에 각각 제시하 였다.

참고로 문장 폭 기억 과제의 핵심인 회상 과제가 한국어와 영어 에서 어떠한 차이를 보이는지 살펴보기 위하여 mixed three-factor $\mathrm{ANOVA}$ (집단, 측정 시기, 언어)를 실시한 결과, 언어에 대한 주효과 만 통계적으로 유의한 결과를 보여 영어 CLPT보다 한국어 CLPT 에서 회상의 정반응률이 높게 나타났고(한국어: $\mathrm{M}=42.41, \mathrm{SE}=2.66$; 영어: $\left.\mathrm{M}=36.80, \mathrm{SE}=2.67 ; F_{(1,20)}=7.17, p<.05, \eta_{\mathrm{p}}^{2}=.264\right)$, 이외 집 단과 측정시기에 대한 주효과 및 3 가지 요인에 따른 이차상호작용 과 삼차상호작용 모두 통계적으로 유의하지 않았다. 이 중 집단에 대한 주효과는 통계적으로 유의하지 않더라도 훈련 집단이 비훈련 집단보다 회상의 정반응률이 높은 경향을 보였다(훈련 집단: $\mathrm{M}=$ $44.51, \mathrm{SE}=3.47$; 비훈련 집단: $\mathrm{M}=34.70, \mathrm{SE}=3.47 ; F_{(1,20)}=4.00$, $\left.p=.059, \eta_{\mathrm{p}}{ }^{2}=.167\right)$.

Table 9. Summary of mixed two-factor ANOVA on Korean CLPT True-False measures

\begin{tabular}{lcccc}
\hline & $F(1,20)$ & $p$-value & partial $\eta^{2}$ & Observed power \\
\hline Main effect & & & & \\
$\quad$ Group & .09 & .774 & .004 & .059 \\
$\quad$ Test time & 6.19 & $.022^{*}$ & .236 & .658 \\
Two-way interaction & & & & \\
$\quad$ Test timexGroup & .01 & .937 & .000 & .051 \\
\hline
\end{tabular}

CLPT $=$ Competing Language Processing Task.

${ }^{*} p<.05$.

Table 10. Summary of mixed two-factor ANOVA on Korean CLPT Word-Recall measures

\begin{tabular}{lrrcc}
\hline & $F(1,20)$ & $p$-value & partial $\eta^{2}$ & Observed power \\
\hline Main effect & & & & \\
$\quad$ Group & 3.76 & .067 & .158 & .454 \\
Test time & .02 & .891 & .001 & .052 \\
Two-way interaction & & & & \\
Test timexGroup & .11 & .749 & .005 & .061 \\
\hline
\end{tabular}

CLPT $=$ Competing Language Processing Task. 
Table 11. Descriptive statistics for WM training and control groups on English CLPT measures

\begin{tabular}{lcclll}
\hline & \multicolumn{2}{c}{ WM training group $(\mathrm{N}=11)$} & & \multicolumn{2}{c}{ Control group (N=11) } \\
\cline { 6 - 6 } \cline { 6 - 6 } & Pre-test & Post-test & & Pre-test & Post-test \\
\hline English CLPT (\%) & & & & & \\
True-False & $81.82(14.88)$ & $92.64(3.91)$ & & $79.00(13.16)$ & $85.93(11.54)$ \\
Word-Recall & $39.18(13.10)$ & $43.72(6.05)$ & & $32.47(17.89)$ & $31.82(15.14)$ \\
\hline
\end{tabular}

Values are presented as mean (SD) of percentage of correct responses. WM= working memory; CLPT = Competing Language Processing Task.

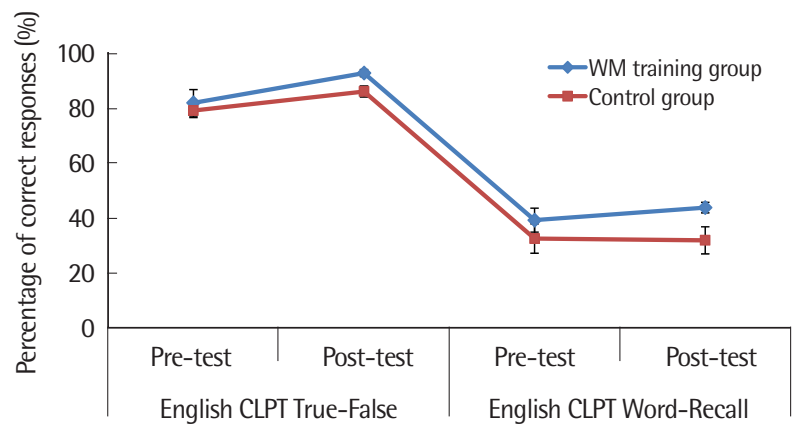

Figure 5. Pre-test and post-test results of working memory (WM) training and control groups on English CLPT measures.

CLPT = Competing Language Processing Task.

\section{논의 및 결론}

본 연구는 국내에 거주하는 5-6세의 학령전기 한국어-영어 이중 언어아동을 대상으로 저장 및 처리의 조합능력을 증진시키기 위한 언어성 작업기억훈련이 읽기 기술과 작업기억능력에 어떠한 영향 을 미치는지 살펴보고자 하였다. 지금까지 한국어-영어 이중언어 아동의 언어 및 작업기억능력에 관한 연구가 일부 진행되었으나 (Hong \& Yim, 2014; Hwang, 2012; Yim et al., 2016), 이중언어아동 을 대상으로 작업기억훈련을 적용한 연구는 발표되지 않았다. 따 라서 본 연구의 결과들은 이중언어아동의 언어 중재에서 특별히 음운인식과 단어재인, 작업기억 과제의 수행력 향상에 언어성 작업 기억훈련의 효과를 검증하는 근거자료로 제시할 수 있을 것이다.

먼저, 작업기억훈련을 받은 훈련 집단과 비훈련 집단 간 음운인 식 과제의 수행력은 훈련 집단이 사전사후 평가에서 음절과 음소 인식 모두 유의한 차이를 보인 반면, 비훈련 집단은 두 과제 모두에 서 유의한 차이를 보이지 않았다. 이는 언어성 작업기억훈련이 이 중언어아동의 음운인식능력을 향상시키고, 작업기억과 읽기 기술 의 높은 상관관계를 보고한 선행연구들(Smith-Spark \& Fisk, 2007; Swanson \& Jerman, 2007)을 뒷받침하는 동시에 읽기 기술 증진을
Table 12. Summary of mixed two-factor ANOVA on English CLPT True-False measures

\begin{tabular}{lcccc}
\hline & $F(1,20)$ & $p$-value & partial $\eta^{2}$ & Observed power \\
\hline Main effect & & & & \\
Group & 1.16 & .294 & .055 & .176 \\
$\quad$ Test time & 15.37 & $.001^{* * *}$ & .435 & .961 \\
Two-way interaction & & & & \\
Test time×Group & .741 & .399 & .036 & .130 \\
\hline
\end{tabular}

CLPT $=$ Competing Language Processing Task. ${ }^{* * *} p<.001$.

Table 13. Summary of mixed two-factor ANOVA on English CLPT Word-Recall measures

\begin{tabular}{lrccc}
\hline & $F(1,20)$ & $p$-value & partial $\eta^{2}$ & Observed power \\
\hline Main effect & & & & \\
$\quad$ Group & 3.04 & .097 & .132 & .382 \\
$\quad$ Test time & .65 & .431 & .031 & .119 \\
Two-way interaction & & & & \\
Test time×Group & 1.15 & .297 & .054 & .175 \\
\hline
\end{tabular}

CLPT = Competing Language Processing Task.

위한 작업기억훈련의 효용성과 필요성을 증명한다. 특히 훈련 집단 은 음절보다 음소인식에서 정반응률이 크게 증가하였는데 이는 음 운인식이 음절, 음소 순으로 발달하며, 미국과 한국 아동 모두 4 세 아동의 $50 \%$ 가 음절을, 5 세 아동의 $50 \%$ 가 음소를 인식한다는 선행 연구들(Goldsworthy, 2003; Stackhouse, 1997; Yoon, 1997)에 근거 하여 본 연구에서 5-6세 아동을 연구 대상자로 선정하였으므로 음 절인식보다는 음소인식에 더 많은 영향을 미쳤으리라 사료된다. 실 제 훈련 전 두 집단의 음절인식의 평균 정반응률은 $85.80 \%-90.91 \%$, 음소인식의 평균 정반응률은 $51.70 \%-63.64 \%$ 로 음소인식의 발달 이 음절인식보다 낮게 나타나작업기억훈련이 발달 진행이 낮은 음 소인식에서 보다 많은 효과를 보였다. 더욱이 훈련 집단은 훈련 전 음소인식의 정반응률이 $51.70 \%$ 로 비훈련 집단의 $63.64 \%$ 보다 훨씬 낮은 수준에서 시작하였음에도 불구하고 훈련 후 훈련 집단의 정 반응률은 $75 \%$, 비훈련 집단은 $61.93 \%$ 로 정반응률이 크게 증가하였 다. 이들 결과에서도 5-6세 연령의 이중언어아동에게는 음절보다 는 음소인식에서작업기억훈련의 효과가 크다는 사실을 알수 있다.

단어재인 과제에서 두 집단은 사전사후 간 유의한 차이를 보였는 데 두 가지 과제 중 무의미단어재인에서만 유의한 차이를 보였고 이들 결과는 음운인식 과제와 동일한 맥락에서 해석할 수 있다. 작 업기억훈련 전 의미단어재인의 평균 정반응률은 훈련 집단이 $98.18 \%$, 비훈련 집단이 $97.27 \%$ 로 국내에 거주하는 5-6세 이중언어아동들 의 의미단어재인이 거의 완성 단계에 이르렀음을 보여준다. 이에 반 
해 낯선 무의미 단어를 자소, 음소 대응 지식을 통해 음운을 해독 하는 능력은 $79.55 \%-81.82 \%$ 로 아직 완전하지 못하다. 의미단어재 인에서의 높은 수행력은 천장효과(ceiling effect)로 작업기억훈련 의 효과 검증을 어렵게 할 수 있으나, 음운인식이 의미단어보다 무 의미단어와 높은 상관을 보인다는 선행연구(Lee \& Park, 1999)에 근거하여 5-6세 아동의 음운인식 발달 수준과 단어재인 발달 수준 을 함께 고려하였을 때 작업기억훈련의 효과가 의미단어보다는 무 의미단어재인에서 크게 작용한 것으로 사료된다. 이는 무의미 단어 가 일견 읽기(sight reading)를 통해 재인될 수 없으므로 의미단어 보다 더 많은 음운처리 기술을 필요로 하며 특히 무의미단어재인에 서 음소인식과 음성 재부호화의 발달 과정에 놓인 5-6세 아동들에 게 작업기억훈련이 음소 및 음절의 조작능력을 활성화시킴으로써 무의미단어재인에 긍정적인 영향을 미친 것으로 해석할 수 있겠다.

한편, 기대와 달리 세 가지 작업기억 과제의 사전사후 평가에서 훈련 집단은 비단어 따라말하기 과제의 정반응률에 유의한 차이 를 보이나, 한국어와 영어의 문장 폭 기억 과제(CLPT)의 정오판단 및 회상의 정반응률에는 유의한 차이를 보이지 않았다. 작업기억 훈련이 한국어와 영어의 CLPT 수행력을 유의하게 향상시키지 못 한 원인으로 CLPT 과제가 비단어 따라말하기보다 인지적으로 더 많은 집중과 더 높은 처리부담(processing load)을 필요로 한다는 점을 고려할 수 있다. 또한, 본 연구에서 작업기억훈련 과제로 CLPT 과제와 유사하게 정보처리 용량의 부담이 크고 난이도가 높은 역 순 단어 폭 작업기억훈련과 이중-처리 작업조건훈련을 통해 작업 기억의 향상을 도모하였으나 훈련 받지 않은 작업기억(CLPT) 과제 에 일반화되는 데 어려움이 있을 수 있으며 10 회기의 비교적 짧은 훈련 기간이 5-6세의 이중언어아동들에게 한국어와 영어의 CLPT 수행력을 유의하게 향상시키지 못한 원인일 수 있겠다. 본 연구는 Lee 등(2015)의 연구에서 작업기억훈련 프로그램에 참여한 아동 들이 10 회기 이상에서 모두 정반응률의 상승을 보인 점에 착안하 여 주 5 회씩 2 주에 걸쳐 총 10 회기를 진행하였으나 국내 작업기억 중재 프로그램을 사용한 선행연구들(Choi, 2011; Ham, 2009; Kim \& Yim, 2015)이 주 3회씩 5-7주에 걸쳐 총 15-21회기의 중재가 실시 된 것과 비교하여 훈련 진행 기간과 횟수가 모두 낮았다.

비단어 따라말하기는 익숙하지 않은 말소리에 대한 음운적 표상 능력과 음운자료를 저장 및 유지하여 산출하는 능력을 평가하는 과제(Gathercole, Willis, \& Baddeley, 1991; Mann \& Liberman, 1984; Shankweiler \& Crain, 1986)인 반면, CLPT는 기능적 작업기 억을 대표하는 과제로 정보의 저장과 처리의 조합기능을 평가한다. Kohnert, Windsor와 Yim (2006)은 문화적 또는 언어적으로 다양 한 배경과 능력을 가진 아동들의 언어장애 진단에서 편향적일 수
있는 경험-의존적 평가 과제를 대체하기 위한 처리-의존적 측정도 구로 CLPT가 이중언어아동들의 언어 능력을 보다 민감하게 평가 할 수 있다고 제안하였다. 한국어 CLPT 과제에서 전체 이중언어 대상자 $(\mathrm{N}=22)$ 의 정오판단 정반응률은 사전검사에서 평균 $92.35 \%$ 로 이는 국내 7-9세 아동들이 94\%의 수행력을 보인 선행연구(Kim \& Yim, 2012)에 비추어 본 연구 대상자가 5-6세 아동임을 고려하였 을 때 한국어 단일언어아동들과 유사한 수행력을 보였다. 그러나 영어 CLPT 과제에서 정오판단의 정반응률은 사전검사에서 평균 $80.41 \%$ 로 이는 영어권의 학령기 6세 아동들이 $97.76 \%$ 의 수행력을 보인 선행연구(Gaulin \& Campbell, 1994)와 비교하여 영어 단일언 어아동들에 비해 훨씬 낮은 수행력을 보였다. 이들 결과는 CLPT정 오판단 검사에서 한국어와 영어의 정반응률 차이에 기인한 것으로 사료된다. 사전검사에서 대상자 전체의 한국어와 영어의 정반응률 차이를 살펴보면 한국어보다 영어 CLPT의 정오판단 정반응률이 통계적으로 유의하게 낮게 나타났다 $\left(t_{(21)}=4.17, p<.001\right)$. 이는 연구 대상자 모두 한국어가 모국어이며 일상생활에서 영어보다 한국어 사용이 많은 이중언어아동을 대상으로 한 결과일 수 있겠다. 실제 22 명의 훈련 및 비훈련 집단의 PPVT-IV 결과를 살펴보면 한국어 와 영어를 함께 제시한 경우 수용어휘 평균이 140.23 점 $(\mathrm{SD}=32.40)$ 으로 8 세 10 개월의 등가연령에 해당하나 영어만 제시한 경우 수용 어휘 평균이 88.14 점 $(\mathrm{SD}=24.39)$ 으로 크게 낮아져 5 세 5 개월의 등 가연령에 해당하였다. 이렇듯 국내에 거주하며 비교적 영어 노출 기간이 길지 않은 미취학 연령의 한국어-영어 이중언어아동들의 환경 및 경험적 제한으로 한국어보다 영어 CLPT의 정오판단 정반 응률이 유의하게 낮게 나타난 것으로 추측된다.

CLPT의 회상 과제에서도 동일하게, 한국어 CLPT 과제에서 전 체 대상자 $(\mathrm{N}=22)$ 의 회상 정반응률은 사전검사에서 평균 $42.24 \%$ 로 국내 7-9세 아동들의 $43 \%$ 수행력(Kim \& Yim, 2012)과 비교하 여 한국어 단일언어아동들과 유사한 수행력을 보인 반면, 영어 CLPT 과제에서 회상의 정반응률은 사전검사에서 평균 $35.82 \%$ 로 영어권의 학령기 6세 아동들의 50.28\%의 수행력(Gaulin \& Campbell, 1994)과 비교하여 영어 단일언어아동들에 비해 훨씬 낮은 수 행력을 보였고, 한국어와 영어의 회상 정반응률의 차이 또한 한국 어보다 영어 CLPT의 회상 정반응률이 유의하게 낮았다 $\left(t_{(21)}=2.70\right.$, $p$ <.05). Ellis Weismer 등(1999)의 연구에 따르면 단순언어장애 아 동들은 일반아동보다 CLPT의 두 가지 과제 중 회상에서만 유의하 게 낮은 수행을 보였고, CLPT의 회상 수행력이 기능적 작업기억용 량의 평가와 함께 처리 자원이 할당되는 효율성을 나타낸다고 제안 하였다. 또한, 국내 어휘발달지체 아동을 대상으로 작업기억 중재 를 실시한 Kim과 Yim (2015)의 연구에서도 중재 이후 CLPT의 두 
가지 과제 중 회상에서만 유의한 향상을 보고하였다. 이들 선행연 구들에 근거하여 작업기억훈련을 받은 이중언어아동들의 한국어 또는 영어의 CLPT 회상 과제에서 정반응률의 향상을 기대하였으 나 본 연구에서는 사전사후 간 유의한 차이를 보이지 못했다.

본 연구의 결과들을 종합해 보면, 비록 작업기억 중재효과의 일 반화에 부분적인 제한점이 있으나 집중적인 언어성 작업기억훈련 은 5-6세 한국어-영어 이중언어아동들의 음운적 기억 및 복잡한 인지적 기능을 향상시켜 음운인식과 단어재인 및 정보의 저장과 처 리를 담당하는 작업기억 과제의 수행력을 유의하게 증진시켰다. 이 는 이중언어아동들의 읽기 기술 중재에서 작업기억훈련의 효과를 입증하며, 본 연구에서 한국어를 모국어로 사용하는 이중언어아 동들을 대상으로 하므로 국내 조기 영어학습과 중재에서 작업기억 훈련의 적용 가능성을 제안할 수 있겠다. 그뿐만 아니라, 어휘발달 지체 아동을 대상으로 한 선행연구(Kim \& Yim, 2015)와 이중언어 아동을 대상으로 한 본 연구의 결과들을 종합하여 작업기억훈련 이 언어 및 읽기 기술을 유의하게 향상시키므로 언어 사용에 어려 움이 있는 의사소통장애 아동들에게 작업기억능력의 평가 및 작 업기억훈련의 활용 가능성을 시사할 수 있겠다.

본 연구의 제한점 및 제언은 다음과 같다. 첫째, 언어성 작업기억 훈련의 효과를 좀 더 명확하게 확인하고 이중언어아동의 특성을 강조하기 위하여 같은 연령대의 단일언어아동을 포함한 후속연구 가 필요하다. 단일언어아동과의 비교는 이중언어아동들의 특성에 맞는 중재 프로그램의 개발 및 적용에 필요한 근거자료를 제공할 것이다. 둘째, 작업기억훈련을 제공하는 기간과 횟수를 늘려 작업 기억 능력의 변화를 촉진시킬 수 있는 기회를 충분히 제공하고 이 와 함께 현재 중재 완료 후 2-3일로 제한한 사후평가의 기간을 연장 하여 중재 효과의 일반화를 보다 정확히 확인하여야 하겠다. 또한, 작업기억훈련 빈도에 따른 수행력의 차이를 비교하여 보다 효율적 인 중재 프로그램을 계획하여야 하겠다. 셋째, 본 연구에서 언어성 작업기억훈련만 실시하였으므로 언어성 및 비언어성 과제를 모두 실시하여 다양한 작업기억훈련을 제시하고 사전사후평가 과제를 세분화함으로써 좀 더 자세한 훈련 효과 분석이 필요하다. 이와 더 불어, 작업기억훈련 방법의 선택 및 개발에서 현재 대표적으로 사 용되는 CogMed, Jungle Memory, n-back 과제와 같은 훈련 프로그 램의 활용을 고려할 수 있겠다. 마지막으로, 훈련 집단이 11 명, 비훈 련 집단이 11 명으로 연구에 참여한 대상자 수가 적어 언어성 작업 기억훈련의 효과를 일반화시키는 것에 한계가 있다. 후속연구를 통 해 대상자의 수를 늘리고 각 연령의 범위를 보다 세분화하여 작업 기억훈련 효과를 파악하는 것이 필요하다.

\section{REFERENCES}

Alloway, T. P. \& Alloway, R. G. (2008). Jungle Memory Training Program. https://lb.junglememory.com/pages/general_content_area?content_area_ $\mathrm{id}=39$

Alloway, T. P., Bibile, V., \& Lau, G. (2013). Computerized working memory training: can it lead to gains in cognitive skills in students? Computers in Human Behavior, 29(3), 632-638.

Alloway, T. P., Gathercole, S. E., Kirkwood, H., \& Elliott, J. (2009). The cognitive and behavioral characteristics of children with low working memory. Child Development, 80(2), 606-621.

Baddeley, A. D. (2000). Short-term and working memory. In E. Tulving \& F. I. M. Craik (Eds.), The Oxford handbook of memory (pp. 77-92). New York, NY: Oxford University Press.

Baddeley, A. D., \& Hitch, G. (1974). Working memory. Psychology of Learning and Motivation, 8, 47-89.

Bialystok, E., Craik, F., \& Luk, G. (2008). Cognitive control and lexical access in younger and older bilinguals. Journal of Experimental Psychology: Learning, Memory, and Cognition, 34(4), 859-873.

Bialystok, E., \& Craik, F. I. (2010). Cognitive and linguistic processing in the bilingual mind. Current Directions in Psychological Science, 19(1), 19-23.

Bialystok, E., \& Majumder, S. (1998). The relationship between bilingualism and the development of cognitive processes in problem solving. Applied Psycholinguistics, 19(1), 69-85.

Bishop, D. V. (1992). The underlying nature of specific language impairment. Journal of Child Psychology and Psychiatry, 33(1), 3-66.

Brehmer, Y., Rieckmann, A., Bellander, M., Westerberg, H., Fischer, H., \& Bäckman, L. (2011). Neural correlates of training-related working-memory gains in old age. Neuroimage, 58(4), 1110-1120.

Brehmer, Y., Westerberg, H., \& Bäckman, L. (2012). Working-memory training in younger and older adults: training gains, transfer, and maintenance. Frontiers in Human Neuroscience, 6, 63.

Brown, G. D. A., \& Hulme, C. (1992). Cognitive psychology and second language processing: the role of short-term memory. Advances in Psychology, $83,105-121$

Campbell, R., \& Sais, E. (1995). Accelerated metalinguistic (phonological) awareness in bilingual children. British Journal of Developmental Psychology, 13(1), 61-68.

Cattell, R. B. (1943). The measurement of adult intelligence. Psychological Bulletin, 40(3), 153-193. 
Choi, S. (2011). The effects of vocabulary acquisition, reading task and selfefficacy of children with learning disabilities by working memory promotion training. The Korea Journal of Learning Disabilities, 8(2), 31-46.

Cohen, J. (1988). Statistical power analysis for the behavioral science (2nd ed.). NY: Academic Press.

Conway, A. R., Cowan, N., Bunting, M. F., Therriault, D. J., \& Minkoff, S. R. (2002). A latent variable analysis of working memory capacity, short-term memory capacity, processing speed, and general fluid intelligence. Intelligence, 30(2), 163-183.

Cowan, N., Nugent, L. D., Elliott, E. M., Ponomarev, I., \& Saults, J. S. (1999). The role of attention in the development of short-term memory: age differences in the verbal span of apprehension. Child Development, 70(5), 1082-1097.

Diaz, R. M. (1985). Bilingual cognitive development: addressing three gaps in current research. Child Development, 56(6), 1376-1388.

Diaz, R. M., Padilla, K. A., \& Weathersby, E. K. (1991). The effects of bilingualism on preschoolers' private speech. Early Childhood Research Quarterly, 6(3), 377-393.

Doosan Donga. (2003). Dong-A's Prime Korean-English dictionary. Seoul: Doosan Donga Corporation.

Dunn, L. M., \& Dunn, D. M. (2007). PPVT-4: Peabody Picture Vocabulary Test. San Antonio, TX: Pearson.

Ellis Weismer, S., Evans, J., \& Hesketh, L. J. (1999). An examination of verbal working memory capacity in children with specific language impairment. Journal of Speech, Language, and Hearing Research, 42(5), 1249-1260.

Gathercole, S. E., \& Alloway, T. P. (2006). Practitioner review: Short-term and working memory impairments in neurodevelopmental disorders: diagnosis and remedial support. Journal of Child Psychology and Psychiatry, 47(1), 4-15.

Gathercole, S. E., Willis, C., \& Baddeley, A. D. (1991). Differentiating phonological memory and awareness of rhyme: reading and vocabulary development in children. British Journal of Psychology, 82(3), 387-406.

Gaulin, C. A., \& Campbell, T. F. (1994). Procedure for assessing verbal working memory in normal school-age children: some preliminary data. Perceptual and Motor Skills, 79(1), 55-64.

Goldsworthy, C. L. (2003). Developmental reading disabilities: a language based treatment approach (2nd ed.). Clifton Park, NY: Thomson.

Ham, E. S. (2009). The effect of working memory training program on the Verbal working memory achievement and language comprehension in children with intellectual disabilities (Master's thesis). Daegu University, Gyeongsan,
Korea.

Han, M. K., Seong, S. Y., \& Choi, S. J. (2016). Words in storybooks as children's language input environment: predicates. Communication Sciences \& Disorders, 21(1), 98-110.

Han, J., \& Yim, D. (2018). Korean brief parent report measures of language development in children with vocabulary delay. Journal of Speech-Language \& Hearing Disorders, 27(2), 69-84.

Hilchey, M. D., \& Klein, R. M. (2011). Are there bilingual advantages on nonlinguistic interference tasks? Implications for the plasticity of executive control processes. Psychonomic Bulletin \& Review, 18(4), 625-658.

Holmes, J., Gathercole, S. E., \& Dunning, D. L. (2009). Adaptive training leads to sustained enhancement of poor working memory in children. Developmental Science, 12(4), F9-F15.

Hong, S., \& Yim, D. (2014). The assessment of language impairment in bilingual children through learning and memory tasks. Communication Sciences \& Disorders, 19(1), 31-44.

Hwang, B. M. (2012). Vocabulary development and phonological short-term memory in Korean-English bilingual children and English monolingual children. Bilingual Research, 50, 329-352.

Hwang, H. S., \& Hwang, H. J. (2000). The language development of bilingual children speaking Korean and English. Korean Journal of Child Studies, 21(4), 69-79.

Jacobson, L. A., Ryan, M., Martin, R. B., Ewen, J., Mostofsky, S. H., Denckla, M. B., \& Mahone, E. M. (2011). Working memory influences processing speed and reading fluency in ADHD. Child Neuropsychology, 17(3), 209224.

Jaeggi, S. M., Buschkuehl, M., Jonides, J., \& Perrig, W. J. (2008). Improving fluid intelligence with training on working memory. Proceedings of the National Academy of Sciences, 105(19), 6829-6833.

Jaeggi, S. M., Buschkuehl, M., Perrig, W. J., \& Meier, B. (2010). The concurrent validity of the N-back task as a working memory measure. Memory, 18(4), 394-412.

Je, H. S. (2014). Effect of emergent literacy skills on monosyllable reading of children with typical development and mild intellectual disability (Doctoral dissertation). Ewha Womans University, Seoul, Korea.

Just, M. A., \& Carpenter, P. A. (1992). A capacity theory of comprehension: individual differences in working memory. Psychological Review, 99(1), 122-149.

Kayser, H. (1995). Assessment of speech and language impairments in bilingual children. In H. Kayser (Ed.), Bilingual speech-language pathology: an 
Hispanic focus (pp. 243-264). San Diego, CA: Singular Publishing Group.

Kim, H., \& Yim, D. (2012). The performance on working memory span task in children with high-function autism. Korean Journal of Communication \& Disorders, 17(3), 451-465.

Kim, J. Y. (2016). The impact of phonological awareness and phonological working memory training on the reading disabilities of children in the early years of elementary school (Master's thesis). Ewha Womans University, Seoul, Korea.

Kim, S., \& Yim, D. (2015). Study of working memory intervention in children with delay in vocabulary development: effects on working memory and language ability. Communication Sciences \& Disorders, 20(4), 469-489.

Kim, Y. T. (in press). Korean Language Processing Assessment for Children (KOLPAC). Seoul: Ewha Womans University.

Kim, Y. T., Hong, G. H., Kim, K. H., Jang, H. S., \& Lee, J. Y. (2009). Receptive \& expressive vocabulary test (REVT). Seoul: Seoul Community Rehabilitation Center.

Klingberg, T. (2010). Training and plasticity of working memory. Trends in Cognitive Sciences, 14(7), 317-324.

Klingberg, T., Fernell, E., Olesen, P. J., Johnson, M., Gustafsson, P., Dahlström, K., ... \& Westerberg, H. (2005). Computerized training of working memory in children with ADHD-a randomized, controlled trial. Journal of the American Academy of Child \& Adolescent Psychiatry, 44(2), 177-186.

Klingberg, T., Forssberg, H., \& Westerberg, H. (2002). Training of working memory in children with ADHD. Journal of Clinical and Experimental Neuropsychology, 24(6), 781-791.

Kohnert, K. (2010). Bilingual children with primary language impairment: Issues, evidence and implications for clinical actions. Journal of Communication Disorders, 43(6), 456-473.

Kohnert, K., \& Windsor, J. (2004). The search for common ground. Part II: Nonlinguistic performance by linguistically diverse learners. Journal of Speech, Language \& Hearing Research, 47(4), 891-903.

Kohnert, K., Windsor, J., \& Yim, D. (2006). Do language-based processing tasks separate children with language impairment from typical bilinguals? Learning Disabilities Research \& Practice, 21(1), 19-29.

Kyllonen, P. C., \& Christal, R. E. (1990). Reasoning ability is (little more than) working-memory capacity? Intelligence, 14(4), 389-433.

Landry, R., \& Allard, R. (1991). Can schools promote additive bilingualism in minority group children. In L. M. Malave \& G, Duquette (Eds.), Language, culture and cognition (pp. 190-197). Clevedon, UK: Multilingual Matters.

Langdon, H. W. (1992). Speech and language assessment of LEP/bilingual
Hispanic students. In H. W. Langdon \& L. L. Cheng (Eds.), Hispanic children and adults with communication disorders (pp. 201-271). Gaithersburg, MD: Aspen Publishers.

Lee, H. J. (2010). The influences of number of syllables and wordlikeness on 3-to 5-year-old Korean-English bilingual children's nonword repetition (Master's thesis). Ewha Womans University, Seoul, Korea.

Lee, H. J., Kim, Y. T., \& Yim, D. (2013). Non-word repetition performance in Korean-English bilingual children. International Journal of Speech-Language Pathology, 15(4), 375-382.

Lee, H. S., \& Park, H. S. (1999). A comparison study of phonological processing and word recognition in reading disabled, reading level matched and age matched children. Korean Journal of Communication \& Disorders, 4(1), 79-102.

Lee, M. J., Hong, S., Shin, G., \& Kim, C. (2015). Development and pilot-study of the working memory training program for children. Journal of Institute for Social Sciences, 26(4), 27-44.

Mann, V. A., \& Liberman, I. Y. (1984). Phonological awareness and verbal short-term memory. Journal of Learning Disabilities, 17(10), 592-599.

McIlwain, J. (2009). DK Children's Illustrated Dictionary. New York, NY: Dorling Kindersley.

Meisel, J. M. (1989). Early differentiation of languages in bilingual children. In K. Hyltenstam \& L. K. Obler (Eds.), Bilingualism across the lifespan: aspects of acquisition, maturity and loss (pp. 13-40). Cambridge, UK: Cambridge University Press.

Ministry of Education. (2016). Educational Statistics in 2016. http://kess.kedi. re.kr.

Montgomery, J. W. (2000a). Relation of working memory to off-line and realtime sentence processing in children with specific language impairment. Applied Psycholinguistics, 21(1), 117-148.

Montgomery, J. W. (2000b). Verbal working memory and sentence comprehension in children with specific language impairment. Journal of Speech, Language, and Hearing Research, 43(2), 293-308.

Montgomery, J. W. (2002). Understanding the language difficulties of children with specific language impairments. American Journal of Speech-Language Pathology, 11(1), 77-91.

Montgomery, J. W., Magimairaj, B. M., \& Finney, M. C. (2010). Working memory and specific language impairment: an update on the relation and perspectives on assessment and treatment. American Journal of SpeechLanguage Pathology, 19(1), 78-94.

Moon, S. B. (2014). Korean version of Kaufman Assessment Battery for Chil- 
dren II (K-ABC-II). Seoul: Hakjisa.

Morales, J., Calvo, A., \& Bialystok, E. (2013). Working memory development in monolingual and bilingual children. Journal of Experimental Child Psychology, 114(2), 187-202.

Morrison, A. B., \& Chein, J. M. (2011). Does working memory training work? The promise and challenges of enhancing cognition by training working memory. Psychonomic Bulletin \& Review, 18(1), 46-60.

Nation, K., Adams, J. W., Bowyer-Crane, C. A., \& Snowling, M. J. (1999). Working memory deficits in poor comprehenders reflect underlying language impairments. Journal of Experimental Child Psychology, 73(2), 139158.

Papadopoulos, T. C., Charalambous, A., Kanari, A., \& Loizou, M. (2004). Kindergarten cognitive intervention for reading difficulties: the PREP remediation in Greek. European Journal of Psychology of Education, 19(1), 79.

Paradis, J., Emmerzael, K., \& Duncan, T. S. (2010). Assessment of English language learners: using parent report on first language development. Journal of Communication Disorders, 43(6), 474-497.

Paradis, J., \& Genesee, F. (1996). Syntactic acquisition in bilingual children: autonomous or interdependent? Studies in Second Language Acquisition, 18(1), 1-25.

Restrepo, A. (1998). Identifiers of predominately Spanish-speaking children with language impairment. Journal of Speech, Language and Hearing Research, 41(6), 1398-1411.

Seo, H. Y., \& Kim, C. B. (2014). Working memory training effects according to domain-specificity: a meta-analysis. Korean Journal of Cognitive and Biological Psychology, 26(4), 207-231.

Shankweiler, D., \& Crain, S. (1986). Language mechanisms and reading disorder: a modular approach. Cognition, 24(1-2), 139-168.

Siegel, L. S., \& Ryan, E. B. (1989). The development of working memory in normally achieving and subtypes of learning disabled children. Child Development, 60(4), 973-980.
Smith-Spark, J. H., \& Fisk, J. E. (2007). Working memory functioning in developmental dyslexia. Memory, 15(1), 34-56.

Stackhouse, J. (1997). Phonological awareness: connecting speech and literacy problems. In B. W. Hodson \& M. L. Edwards (Eds.), Perspectives in applied phonology (pp. 157-196). Gaithersburg, MD: Aspen Publishers.

Swanson, H. L., \& Berninger, V. (1995). The role of working memory in skilled and less skilled readers' comprehension. Intelligence, 21(1), 83-108.

Swanson, H. L., \& Jerman, O. (2007). The influence of working memory on reading growth in subgroups of children with reading disabilities. Journal of Experimental Child Psychology, 96(4), 249-283.

Unsworth, N., \& Engle, R. W. (2007). The nature of individual differences in working memory capacity: active maintenance in primary memory and controlled search from secondary memory. Psychological Review, 114(1), 104-132.

Vellutino, F. R., Scanlon, D. M., \& Spearing, D. (1995). Semantic and phonological coding in poor and normal readers. Journal of Experimental Child Psychology, 59(1), 76-123.

Williams, D. L., Goldstein, G., \& Minshew, N. J. (2006). The profile of memory function in children with autism. Neuropsychology, 20(1), 21-29.

Wong Fillmore, L. (1991a). When learning a second language means losing the first. Early Childhood Research quarterly, 6(3), 323-346.

Wong Fillmore, L. (1991b). A question for early-childhood programs: English first or families first. Education Week, 10(39), 32-34.

Yang, J., Peng, J., Zhang, D., Zheng, L., \& Mo, L. (2017). Specific effects of working memory training on the reading skills of Chinese children with developmental dyslexia. PLoS One, 12(11), e0186114.

Yim, D., Jo, Y., Han, J., \& Seong, J. (2016). Executive function in Korean-English bilingual children with and without vocabulary delay. Communication Sciences \& Disorders, 21(3), 472-487.

Yoon, H. K. (1997). A study on the Hangul reading development: acquisition of grapheme-phoneme correspondence rule (Doctoral dissertation). Pusan National University, Busan, Korea. 
Appendix 1. Word lists of word span backward training task (22 animal nouns)

\begin{tabular}{|c|c|}
\hline & 동물 단어 \\
\hline 2음절 단어 & $\begin{array}{l}\text { 개미, 거북, 고래, 기린, 문어, 낙타, 매미, 타조, 까치, 펭귄, } \\
\text { 표범, 수달, 사자, 악어, 사슴, 염소, 오리, 늑대, 팬더, 나비, } \\
\text { 돼지, 거미 }\end{array}$ \\
\hline
\end{tabular}

Appendix 2. Vocabulary categories and word lists of dual-load condition training task ( 5 categories, 5 words for each category)

\begin{tabular}{ccccc}
\hline 옷 & 신체 & 탈 것 & 동물 & 과일 \\
\hline 단추 & 배꼽 & 썰매 & 생쥐 & 딸기 \\
양말 & 입술 & 택시 & 토끼 & 자두 \\
모자 & 무릎 & 트럭 & 여우 & 사과 \\
바지 & 가슴 & 버스 & 치타 & 멜론 \\
외투 & 다리 & 기차 & 하마 & 수박 \\
\hline
\end{tabular}




\section{국문초록}

\section{학령전기 한국어-영어 이중언어아동의 언어성 작업기억훈련이 음운인식, 단어재인 및 작업기억 과제 수행력에 미치는 효과}

김윤아 ${ }^{1} \cdot$ 박희영 ${ }^{2}$ 김영태 ${ }^{2}$

'Lions Haven for the Aged, ${ }^{2}$ 이화여자대학교 대학원 언어병리학과

배경 및 목적: 본 연구는 학령전기 한국어-영어 이중언어아동을 대상으로 언어성 작업기억훈련이 음운인식 및 단어재인, 작업기억 능 력에 미치는 효과를 살펴보고자 하였다. 방법: 한국어를 모국어로 사용하고 3세 이후에 영어를 습득한 만 4-5세의 이중언어아동 22명 을 작업기억훈련 집단 11 명과 비훈련 집단 11 명으로 나누어 언어성 작업기억훈련인 단어폭 과제와 이중-처리작업조건 과제를 실시하여 사전사후의 음운인식(음소인식, 음절인식)과 단어재인(의미단어, 무의미단어), 작업기억(정순, 역순의 비단어 따라말하기, 한국어 문장 폭 기억, 영어 문장폭 기억) 능력을 비교하여 훈련효과의 유무를 검증하였다. 결과: 훈련집단은 언어성 작업기억훈련 이후 음운인식 과 제의 음절과음소인식 모두 정반응률이 유의하게 증가하였고 단어재인 과제 중 무의미단어 재인의 정반응률이 유의하게 증가하였다. 3 가지 작업기억 과제에서 훈련집단은 비단어 따라말하기 과제의 정순과 역순 따라말하기 모두 정반응률이 유의하게 증가하였으나 한 국어와 영어의 문장폭 기억 과제의 정오판단과 회상의 정반응률은 유의한 증가를 보이지 않았다. 이에 반해 비훈련 집단은 음운인식과 단어재인, 작업기억 과제 모두에서 사전사후에 유의한 차이를 보이지 않았다. 논의 및 결론: 본 연구는 언어성 작업기억훈련이 이중언 어아동들의 음운인식 및 단어재인, 언어 처리와 관련된 작업기억능력을 향상시킴을 보여준다. 이는 이중언어아동들의 읽기 기술 중재 에서 언어성 작업기억훈련의 효과를 입증하는 근거자료로 활용될 수 있다.

핵심어: 학령전기 이중언어, 언어성 작업기억훈련, 음운인식, 단어재인, 비단어 반복, 문장폭 기억 과제

본 논문은 제1저자의 이화여자대학교 일반대학원 언어병리학전공 석사학위논문을 발췌 및 수정한 것임.

본 연구는 2018년 대한민국 교육부와 한국연구재단의 지원을 받아 수행된 연구임(No. NRF-2018S1A3A2075274).

\section{참고문헌}

교육부(2016). 2016년 교육통계.http://kess.kedi.re.kr.

김신영, 임동선(2015). 어휘발달지체 아동을 대상으로 한 작업기억 중재가 작업기억 및 언어능력에 미치는 영향. Communication Sciences \& Disorders, 20(4), 469-489.

김영태, 홍경훈, 김경희, 장혜성, 이주연(2009). 수용·표현어휘력검사(REVT). 서울: 서울장애인종합복지관.

김지윤(2016). 음운인식 및 음운 작업기억 훈련이 초등학교 저학년 읽기부진 아동의 읽기능력에 미치는 효과. 이화여자대학교 대학원 석사학위논문. 김희진, 임동선(2012). 과제 난이도에 따른 고기능 자폐아동의 작업기억 수행능력. 언어청각장애연구, 17(3), 451-465.

두산동아사서편집국(2003). 동아프라임 한영사전. 서울: 두산동아.

문수백(2014). 카우프만 아동지능검사 II (K-ABC-II). 서울: 학지사.

서희영, 김초복(2014). 영역 특수성에 따른 작업기억의 훈련 효과. 한국심리학회지: 인지 및 생물, 26(4), 207-231.

윤혜경(1997). 아동의 한글읽기발달에 관한 연구:자소-음소대응규칙의 터득을 중심으로. 부산대학교 대학원 박사학위논문.

이명진, 홍선주, 신경희, 김초복(2015). 아동용작업기억 훈련 프로그램 개발 및 예비연구. 사회과학연구, 26(4), 27-44.

이현정(2010). 음절길이와 단어유사성이 3-5세 한국어-영어 이중언어아동의 비단어 따라말하기 수행에 미치는 영향. 이화여자대학교 대학원 석사학 위논문.

이혜숙, 박현숙(1999). 읽기장애 아동과 비장애 아동의 음운처리과정 및 읽기재인간 비교 연구. 언어청각장애연구, 4(1), 79-102.

임동선, 조연주, 한지윤, 성지민(2016). 한국어-영어 이중언어사용 아동의 어휘발달지연 유무에 따른 집행기능 비교. Communication Sciences \& 
Disorders, 21(3), 472-487.

제현순(2014). 초기 문해력 기술들이 일반아동 및 지적장애아동의 1음절읽기 능력에 미치는 영향. 이화여자대학교 대학원 박사학위논문. 최세민(2011). 작업기억 활성화 훈련이 학습장애아동의 어휘습득과 언어과제수행 및 자기효능감에 미치는 영향. 학습장애연구, 8(2), 31-46. 한민경, 성시연, 최서진(2016). 아동의 어휘발달 촉진을 위한 언어입력 환경으로서의 동화책 어휘 연구: 용언을 중심으로. Communication Sciences \& Disorders, 21(1), 98-110.

한지윤, 임동선(2018). 부모 보고형 아동 언어 능력 평가도구(KBPR)의 표준화를 위한 예비연구. 언어치료연구, 27(2), 69-84.

함은선(2009). 작업기억훈련 프로그램이 지적장애아동의 언어이해 및 언어성 작업기억 수행에 미치는 효과. 대구대학교 석사학위논문. 홍선미, 임동선(2014). 학습 및 기억과제를 통한 이중언어아동의 언어발달지체 평가. Communication Sciences \& Disorders, 19(1), 31-44. 황보명(2012). 한국어-영어 이중언어 아동과 영어 단일언어 아동의 어휘발달 및 음운단기기억. 이중언어학, 50, 329-352.

황혜신, 황혜정(2000). 이중언어(한국어-영어)를 하는 아동의 언어능력발달에 관한 연구. 아동학회지, 21(4), 69-79.

\section{ORCID}

김윤아(https://orcid.org/0000-0002-9336-5193); 박희영(https://orcid.org/0000-0001-6714-5843); 김영태(https://orcid.org/0000-0003-1738-6862) 